\title{
ABOVEGROUND NET PRIMARY PRODUCTIVITY AND COVER OF VEGETATION EXPOSED TO VARIOUS DISTURBANCES IN ARID ARGENTINA
}

\author{
BUSSO, C. A. ${ }^{1,2, *}$ - MONTENEGRO, O. A. ${ }^{3}$ - TORRES, Y. A. ${ }^{4}$ - GIORGETTI, H. D. ${ }^{3}-$ \\ RODRIGUEZ, G. D. ${ }^{3}$ \\ ${ }^{I}$ Departamento de Agronomía, Universidad Nacional del Sur (UNS) \\ San Andrés, 8000 Bahía Blanca, Pcia. Buenos Aires, Argentina \\ (phone: +54-0291-459-5102; fax: +54-0291-459-5127) \\ ${ }^{2}$ CERZOS- Consejo Nacional de Investigaciones Cientificas y \\ Tecnológicas de la República Argentina (CONICET) \\ San Andrés, 8000 Bahía Blanca, Pcia. Buenos Aires, Argentina. \\ ${ }^{3}$ Chacra Experimental Patagones, Ministerio de Asuntos agrarios \\ 8504 Carmen de Patagones, Pcia. Buenos Aires, Argentina. \\ ${ }^{4}$ Departamento de Agronomía, Universidad Nacional del Sur (UNS) \\ CIC Pcia. Buenos Aires \\ *Corresponding author \\ e-mail: carlosbusso1@gmail.com \\ (Received $29^{\text {th }}$ Oct 2015 ; accepted $26^{\text {th }}$ Feb 2016)
}

\begin{abstract}
We contrasted total herbaceous ANPP and cover between various disturbance types (Control, Burning, Shrub Control, Old Field 1, Old Field 2, Overgrazing) at a functional group (CSPG $=$ coolseason perennial grasses; $\mathrm{WSPG}=$ warm-season perennial grasses; $\mathrm{CSAG}+\mathrm{D}=$ cool-season annual grasses + dicots) and a species scale during 1984-1992. Results showed that (1) precipitation appeared to be more important than disturbance type in determining total ANPP (CSPG + WSPG + CSAG + Dicots); (2) CSPG made the greatest $(\mathrm{P}<0.05)$ contribution to ANPP and plant cover compared with that made by the other two functional groups in all disturbance types and years; (3) the preferred, late-seral Nassella clarazii and Poa ligularis showed a greater $(\mathrm{P}<0.05)$ ANPP than the earlier-seral, intermediate Pappostipa speciosa and non-preferred Amelichloa ambigua and N. trichotoma in 23 out of 27 comparisons in the Control, Burning and Shrub Control disturbance types. In the Old Field 1, Old Field 2 and Overgrazing disturbance types, however, N. clarazii, P. ligularis, P. speciosa, A. ambigua and $N$. trichotoma showed a similar (P>0.05) ANPP most of the times during 1984-1992; (4) Total plant cover of CSAG+D was most often greater $(\mathrm{P}<0.05)$ than that of WSPG at the Old Field 1 and Overgrazing disturbances.
\end{abstract}

Keywords: aboveground net primary productivity, plant cover, disturbances, late- and early-seral plant species, Argentina

Abbreviations: ANPP: Aboveground net primary productivity; CSPG, Cool-season perennial grasses; WSPG: Warm season perennial grasses; CSAG + D: Cool-season annual grasses + Dicots

Plant nomenclature: Instituto de Botánica Darwinion. Access date: 13 March 2015 http://www2.darwin.edu.ar/Proyectos/FloraArgentina/BuscarEspecies.asp

\section{Introduction}

Assessment of annual net primary productivity (ANPP) is important for planning range development (Le Houérou et al., 1988). Various disturbances can produce dynamic shifts on ANPP or total herbaceous plant cover: burning (Wright and Bailey, 
1982), control of woody vegetation using herbicides (Meyer and Bovey, 1985), removal of woody plants (Vallentine, 1990), and overgrazing (Vallentine, 1990). Use of these disturbances as a management tool is expected to increase the forage value of the treated area. Despite the relative impacts of these disturbances might vary in concert with climatic variations (e.g., precipitation: Le Houérou et al., 1988) and post-treatment management (Gartner, 1988), no studies have evaluated the effects of any of these disturbances on ANPP or plant cover during several years after their occurrence. Some studies have compared the effects of (1) ungrazed lands or (2) burning or (3) woody vegetation control using herbicides or (4) long-term undisturbed lands previously exposed to cultivation with those of long-term, abusive overgrazing on ANPP (Holechek, 1981; Fernández and Busso, 1999; Moreira et al., 2012). These studies have reported a lower ANPP and/or rangeland degradation on areas exposed to severe, abusive overgrazing.

Several studies have reported the effects of various disturbances on vegetation cover at a scale of individual plant species or functional groups. Fire, together with grazing and precipitation, is a major factor in shaping plant community structure in the Phytogeographical Province of the Caldenal, in semiarid, temperate, central Argentina (Distel and Bóo, 1996; Busso, 1997). Thousands of hectares of natural grassland are burnt every year at the south of the Caldenal (Bóo, 1990). However, the frequency of fire occurrence has decreased notably since the introduction of domestic livestock; the high grazing pressures altered the natural fire regimes because of the reduction of fine combustible material (Peláez et al., 2003). As a result, grasslands were transformed to either shrublands or areas of unpalatable grass species for domestic livestock (Pelaez et al., 2003). However, Distel and Bóo (1996) proposed that appropriate management of the frequency and intensity of fire could revert the processes of scrub formation and the presence of unpalatable grasses to states with less bushes and a greater cover of palatable perennial grasses. Several studies have reported an increase in the cover of palatable, rangeland forage species after the shrub stratum was controlled using various herbicides (Baker et al., 1980; Martin and Morton, 1980; Jacoby and Meadors, 1982). Cramer et al. (2008) reported that the abandonment of traditional agricultural lands in some areas can create old fields that require limited or no restoration. In Patagonia, plant communities are characterized by a low vegetation cover which may range from $10 \%$ in the most arid areas to $60 \%$. They have been used as grazing areas since the early 90 's. As reported for other ecosystems, grazing causes an overall reduction of plant cover through the decrease in cover, or eventually the extinction, of palatable grass species (Schlesinger et al., 1990; Bertiller, 1996). Deflation and deposition processes, and organic matter and nutrient losses, are triggered by wind and precipitation after grazing, thus creating large areas of bare soil (Mazzarino et al., 1998). Fernández and Paruelo (1993) have reported that cover of the most palatable grass species (i.e., Poa ligularis) decreases, while that of the non-palatable grass species (i.e., Amelichloa ambigua) increases after grazing in the Occidental District of Patagonia. These changes are triggered by the direct effect of grazing (Sala, 1988), which may lead to plant death in extreme cases, or by indirect effects following cover reduction, such as erosion, and losses of soil organic matter, nutrients, and seeds that limit plant establishment (Bertiller, 1998). The increase of the relative or absolute shrub cover, and the decrease of the absolute cover of perennial grasses, occur as an extended process in grazed rangelands of Patagonia (Perelman et al., 1997). These studies have determined the benefits of using either fire or shrub control using herbicides or management of 
abandoned, previously-cultivated lands or proper grazing as management tools to improve rangeland forage production. However, no studies have compared the relative effects of these disturbance types occurring at the same time in determining the plant cover of palatable rangeland species.

A major determinant of the structure and function of terrestrial ecosystems is precipitation (Webb et al., 1983). However, the relative importance of precipitation or disturbance type in modifying the ANPP of herbaceous vegetation has not been studied to date. These studies are essential in arid zones where small precipitation events $(<5$ $\mathrm{mm}$ : Sala and Lauenroth, 1982) are common. For example, more than $60 \%$ of the rainfall events (mean=1983-2000) might be $<5 \mathrm{~mm}$ at the study site of the current research work (Páez et al., 2005).

The relative abundance of $\mathrm{C}_{3}$ and $\mathrm{C}_{4}$ plants can be controlled by the interaction between precipitation and temperature (Huang et al., 2001). Liu et al. (2005) demonstrated that increased $\mathrm{C}_{4} / \mathrm{C}_{3}$ ratios are positively correlated with higher temperatures. However, at sites with less than $500 \mathrm{~g} / \mathrm{m}^{2}$, annual precipitation is more strongly correlated than temperature to ANPP (Huxman et al., 2004).

The effects of various abiotic and biotic disturbances (e.g., drought, fire, soil tillage, pesticide applications, herbivory) on ANPP and total herbaceous plant cover have been assessed mostly at a plant species scale (Bedunah and Sosebee, 1995; Flemmer et al., 2003; Peláez et al., 2010; Köhl et al., 2014). However, research of the effects of these disturbances on those parameters at a plant functional group scale is rather scarce. Thus, this information is important to have a more generalized scenario on how various disturbance types might affect productivity and total herbaceous plant cover of the species within any of those functional groups under local climate conditions.

Poa ligularis Nees ex Steud, Nassella clarazii (Ball) Barkworth, N. tenuis (Phil.) Barkworth, Pappostipa speciosa (Trin. \& Rupr.) Romasch., Amelichloa ambigua (Speg.) Arriaga \& Barkworth and N. trichotoma (Nees) Hack. Ex Arech. are abundant $\mathrm{C}_{3}$ perennial, native grass species (please see Table 1 for a complete species listing) in semiarid, temperate rangelands of central Argentina (Rúgolo de Agrasar et al., 2005). These species regrow in late summer, early fall, remain vegetative during winter, and flower and set seed in spring and early summer, when become dormant until the next growing season (Cano, 1988). However, the abundance of any of these species at any one time depends, at least partially, upon grazing and fire management of the vegetation (Busso, 1997). Various studies have determined that the late-seral $N$. clarazii and $P$. ligularis are more competitive grass species than the earlier-seral $N$. tenuis, $N$. trichotoma, A. ambigua or P. speciosa (Moretto and Distel, 1997, 1999; Saint Pierre et al., 2004a,b,c; Cenzano et al., 2013). The WSPG [mostly the $\mathrm{C}_{4}$ Sporobolus cryptandrus (Torr.) A. Gray , Aristida spp.and Pappophorum vaginatum Fries] start their growing cycle during November (mid spring), flower and produce fruits during early summer (December) until early fall (May), when plants enter into their dormant stage. Coolseason annual grasses and dicots [mostly Bromus hordaceus L., Schismus barbatus (L.) Thellung, Medicago minima (L) Grufberg and Erodium cicutarium (L.) L'Herit. et Ait] complete their life cycle within the period from fall to spring (Cano, 1988). Greater competitive ability in various $\mathrm{C}_{3}$ or $\mathrm{C}_{4}$ perennial grass species in central Argentina has been attributed to several traits like higher rates of nutrient uptake, root length density, root proliferation, mycorrhizal colonization of the root system, and more often greater relative growth rates of aboveground tissues (Moretto and Distel, 1999; Saint Pierre et al., 2002; Saint Pierre et al., 2004 a,b; Busso et al., 2008, Torres et al., 2013). However, 
no studies have yet addressed the effects of various disturbance types on the ANPP and plant cover of the study plant species.

Table 1. Species composition and its degree of preference by livestock on each of the study functional groups (i.e., CSPG $=$ cool-season perennial grasses; $W S P G=$ warm-season perennial grasses; $C S A G+D=$ cool-season annual grasses + dicots $)$.

\begin{tabular}{|c|c|c|}
\hline Functional & Dominant herbaceous vegetation & Preference by \\
\hline \multirow{13}{*}{ CSPG } & Nassella tenuis (Phil.) Barkworth & Preferred \\
\hline & Nassella longiglumis (Ball) Barkworth & Preferred \\
\hline & Poa ligularis Nees ex Steud & Preferred \\
\hline & Jarava plumose (Spreng.) SLW Jacobs \& & Preferred \\
\hline & Piptochaetium napostaense (Speg.) & Preferred \\
\hline & Poa lanuginosa Poir & Preferred \\
\hline & Bromus brevis Nees ex Steud & Preferred \\
\hline & Koeleria permollis Nees ex Steud & Preferred \\
\hline & Pappostipa speciosa (Trin. \& Rupr.) & Intermediate \\
\hline & Amelichloa ambigua (Speg.) Arriaga \& & Not preferred \\
\hline & Amelichoa brachychaeta (Godr.) Arriaga & Not preferred \\
\hline & Nassella trichotoma (Nees) Hack. Ex & Not preferred \\
\hline & Sporobolus rigens (Trin.) E. Desv. & Not preferred \\
\hline \multirow{6}{*}{ WSPG } & Pappophorum vaginatum Buckley & Preferred \\
\hline & Sporobolus cryptandrus (Torr.) A. Gray & Preferred \\
\hline & Aristida spegazzinii Arechav. & Intermediate \\
\hline & Aristida subulata Henrard & Intermediate \\
\hline & Aristida pallens Cav. & Intermediate \\
\hline & Aristida trachianta Henrard & Intermediate \\
\hline \multirow{7}{*}{ CSAG + Dicots } & Bromus hordeaceus L. & Preferred \\
\hline & Schismus barbatus (L.) Thellung & Preferred \\
\hline & Vulpia megalura (Nutt.) Rydb & Preferred \\
\hline & Lolium multiflorum Lam. & Preferred \\
\hline & Hordeum murinum (Link) Arcang & Preferred \\
\hline & Medicago minima (L.) Grufberg & Preferred \\
\hline & Erodium cicutarium (L.) L'Herit. ex Ait & Preferred \\
\hline
\end{tabular}

Our objective was to compare the dynamics of total ANPP (ANPP), and total herbaceous plant cover, between different functional groups and plant species exposed to various disturbance types in northwestern Patagonia, Argentina. We hypothesized that (1) CSAG + D show a greater ANPP and plant cover at sites exposed to a severe overgrazing than at the other disturbance types, and (2) ANPP and/or plant cover are greater (a) in the CSPG than in the WSPG and CSAG + D, and (b) in the late-seral, more competitive $N$. clarazii or P. ligularis than in the earlier seral, less competitive $N$. tenuis, $N$. trichotoma, A. ambigua, or P. speciosa in all study disturbance types and years. 


\section{Materials and methods}

\section{Study site}

Studies were performed in the Chacra Experimental de Patagones, Buenos Aires, Argentina (40³9'49.7'S, 62 53'6.4'W; 40 m.a.s.1.), within the Phytogeographical Province of the Monte (Cabrera, 1976) during 1984 through 1992. Long-term (19812011) mean monthly temperature and precipitation data are shown in Figure 1.
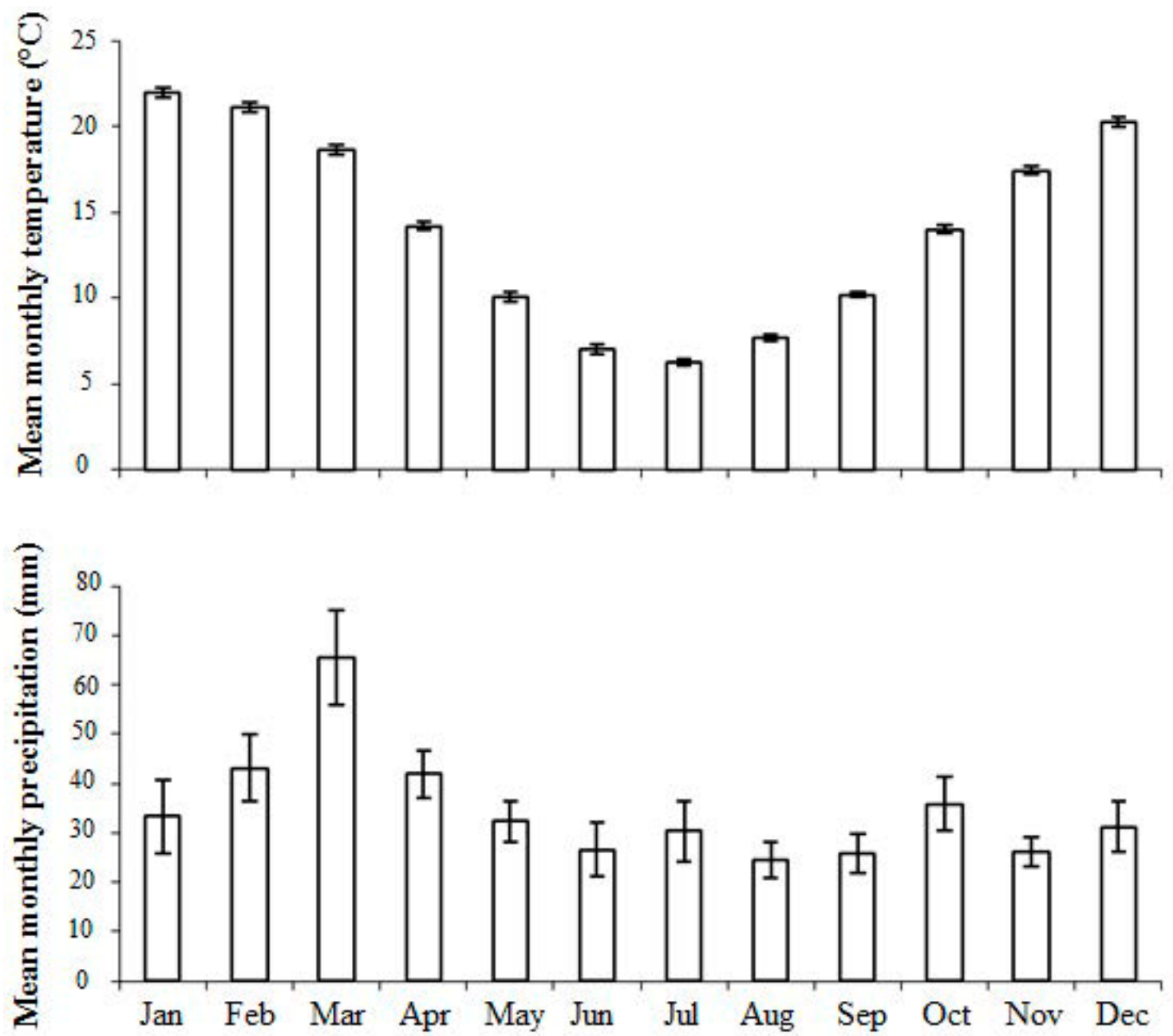

Figure 1. Long-term (1981 to 2011) mean monthly temperatures and precipitations. Vertical bars represent $\pm 1 S E$ of the long-term mean.

Various climatic parameters were obtained from 1984 to 1992 using a meteorological station located at $1 \mathrm{~km}$ away from the study area (Figures 2 and 3).

Climate is temperate semiarid, with higher precipitations during the spring and fall seasons (Giorgetti et al., 2000). Values for climatic variables during 1901-1950 were: mean annual temperature: $14.6^{\circ} \mathrm{C}$ : absolute minimum temperature: $-7.6^{\circ} \mathrm{C}$ (August): absolute maximum temperature: $43{ }^{\circ} \mathrm{C}$ (January); mean annual relative humidity: $60 \%$, and mean annual wind speed: $13 \mathrm{~km} \mathrm{~h}^{-1}$.

Soil is a typical haplocalcid, with an A horizon having a loamy-clay-sandy texture; $0.20 \mathrm{~m}$ deep; $1.69 \%$ organic matter; $28.7 \mathrm{ppm}$ available phosphorus, $0.123 \%$ total 
nitrogen. $\mathrm{AB}_{\mathrm{w}}$ horizon was found below $0.20 \mathrm{~m}$ of soil depth followed by a $\mathrm{BC}_{\mathrm{k}}$ horizon between 0.28 and $0.43 \mathrm{~m}$ depth. $\mathrm{A}_{\mathrm{k}}$ horizon existed below $0.43 \mathrm{~m}$ with very scarce roots. Average $\mathrm{pH}$ was 7.

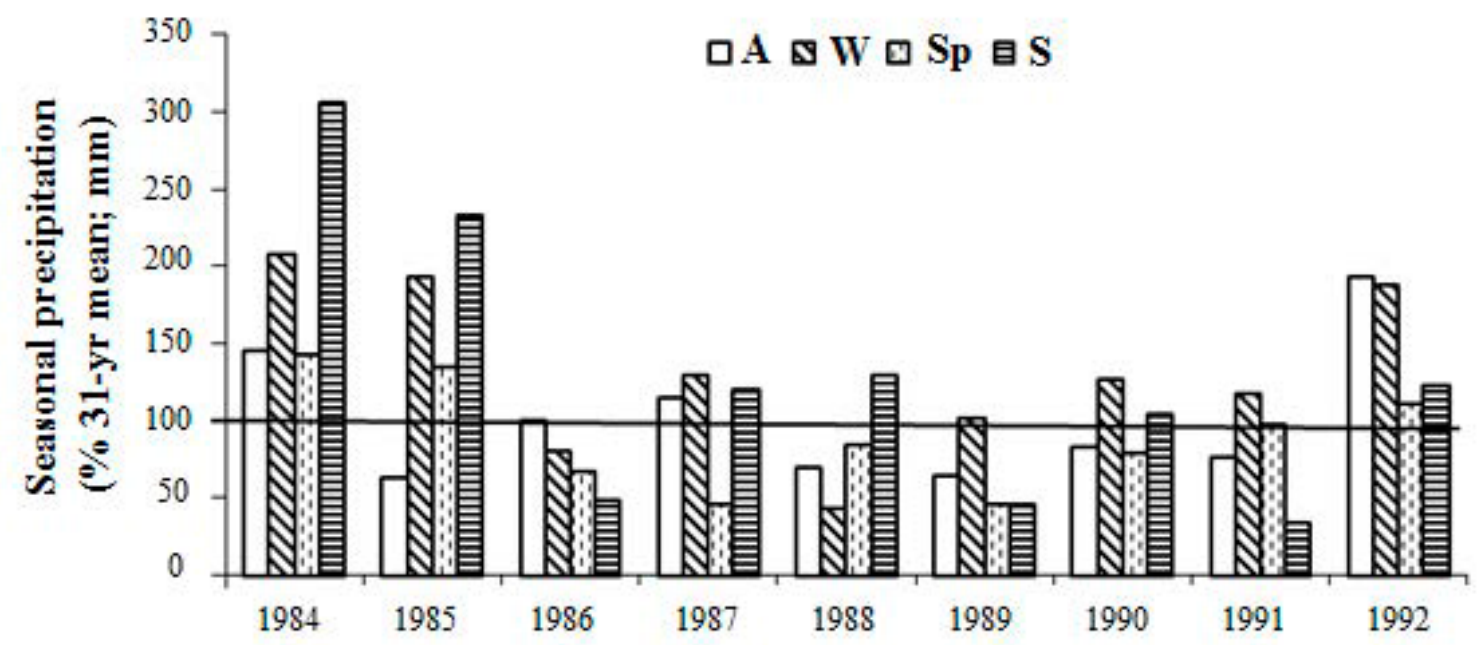

Figure 2. Seasonal precipitation during each year of the study period (1984-1992). For any given year, each histogram represents the percentage contribution of any season to the longterm average (1981-2011) for that season. The horizontal line (417.6 mm: 100\%) indicates the long-term average precipitation. $A=$ Autumn; $W=$ Winter $;$ Sp= Spring; $S=$ Summer.

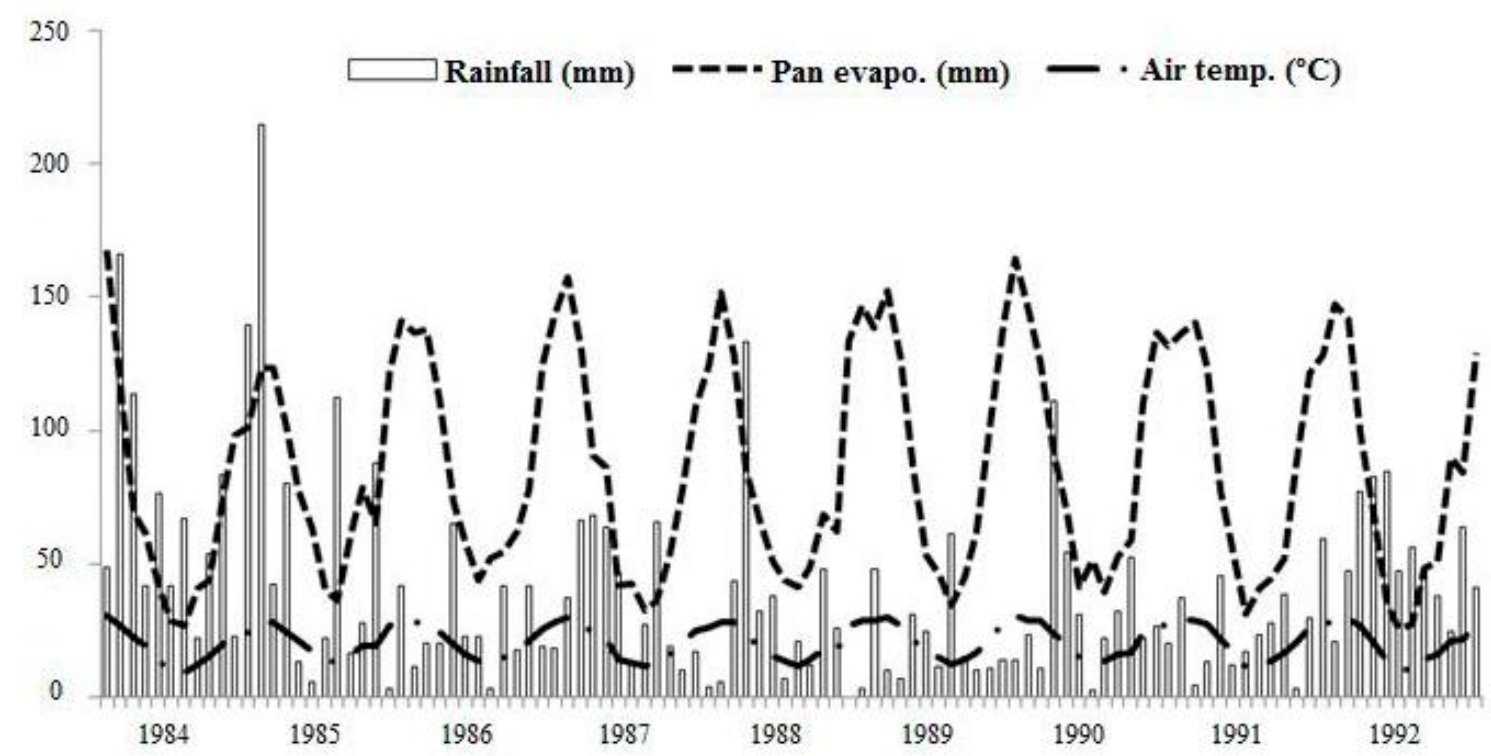

Figure 3. Monthly precipitation, air temperature and pan evaporation during 1984 to 1992.

The plant community is characterized by an open, shrubby stratum which includes different-quality, herbaceous species for cattle production (Busso, 1997). Dominance of a particular grass or shrubby species in the study region is partially dependent on grazing history and fire frequency and intensity (Distel and Bóo, 1996). 
Labour and budget constraints made replication of this study in space and time impossible. Despite emphasis is placed on statistical differences, caution is called for extrapolating the results of this study. These should be better viewed under the specific conditions they were obtained.

\section{Disturbances}

Before disturbances were imposed at the study site, the plant community was characterized ( $\mathrm{n}=20$ stands) by using the abundance-dominance/sociability index of Braun Blanquet (Mueller-Dombois and Ellenberg, 1974) on 1 November 1974. Chuquiraga erinacea $($ mean $=2.3)$, Bacharis ulicina $($ mean $=1.2)$ and Nassella tenuis (mean $=4.4$ ) were the species with the highest index for the shrubby, forb and grass layers, and the community was then classified as an open shrubland of Ch. erinaea and Condalia microphylla within a continuous herbaceous layer of $N$. tenuis. The study was initiated thereafter on areas which had been previously exposed to continuous grazing by cattle and sheep, and then exposed to different managements. One area (20 ha) was cleared of trees and undergrowth, and cropped from 1951 until 1975. Previous to cultivation, half of this area (Old Field 1: OF1) had been exposed to a more severe grazing than the other half (Old Field 2: OF2) because of its greater proximity to a water source for animals. During this period, an adjacent area (95 ha) which had not been cleared was grazed by cattle and sheep. Access of domestic herbivores was then excluded in both areas from 1975 to 1993 . However, the 95 ha area was exposed to three different managements between December 1977 and March 1978: one site ( $34 \mathrm{ha}$ ) remained untreated (control: C), another site ( $37 \mathrm{ha}$ ) was burned (burned: B), and herbicides (shrub control: Sc) were applied on the third site (24 ha) for controlling shrubs. The last studied area was an adjacent site which had been severely overgrazed (overgrazing: O) until 1981, and then excluded from domestic herbivory until 1993.

Burning was conducted on 3 March 1978. At this time, maximum and mean air temperatures were 23.5 and $14.4{ }^{\circ} \mathrm{C}$, respectively, mean relative humidity was $49 \%$, and wind speed and dry weight of fine fuel load were $22 \mathrm{~km} \mathrm{~h}^{-1}$ and $438 \mathrm{~kg} \mathrm{ha}^{-1}$, respectively. More than or equal to $50 \%$ of plants of the shrubs Geoffroea decorticans, Condalia microphylla, Lycium chilensis, Chuquiraga erinacea, Larrea divaricata and Schinus fasciculatus had produced basal regrowth one year after burning. Digiuni (1983) has already reported the chemical shrub control for this study. Briefly, an aerial application of Tordon $213\left(21 \mathrm{ha}^{-1}\right)$ and 2,4,5,-T $\left(41 \mathrm{ha}^{-1}\right)$ was made on 29 December 1977, when mean air temperature and relative humidity were $18.7{ }^{\circ} \mathrm{C}$ and $58.0 \%$, respectively, rainfall was $108 \mathrm{~mm}$ during December, and shrubs were at the reproductive morphological stage of development. Herbicides were very effective in producing death or total defoliation with no basal regrowth in $G$. decorticans, $C$. microphylla, L. chilensis and L. divaricata, and less than $50 \%$ defoliation in $C$. erinacea immediately after their application. Sixteen months later, however, 80-90\% of $G$. decorticans and $C$. microphylla plants had not produced any regrowth, but the remaining plants and those of $L$. chilensis, $C$. erinacea and $L$. divaricata were less than 50\% defoliated. Lack of enough manpower at the research station, however, prevented us to study how shrubs recovered afterwards. 


\section{Procedures}

By mid-November 1978, percentage cover was determined per species within each disturbance type $(n=50)$ by randomly distributing $20 \times 20 \mathrm{~cm}$ quadrats following the canopy-cover method of Mueller-Dombois and Ellenberg (1974). Maximum aboveground standing crop was also estimated at the Control, Old Field 1, Old Field 2, Burned and Shrub Control disturbance type sites in $1978(\mathrm{n}=50)$, and at these and the Overgrazed site from 1984 to 1992. In late January 1984 for the CSPG and the CSAG + Dicots, and late May-early June 1984 for the WSPG, plants of the species pertaining to the various functional groups were clipped at their dormant (i.e., physiologically inactive) morphological stage of development (Rúgolo et al., 2005). In this way, this clipping did not act as a clipping treatment, and allowed that only current year's growth was included in the subsequent once-a-year harvests from 1984 to 1992 (i.e., January or May). Similar to that reported by Singh et al. (1975), aboveground standing crop [i.e., live + recent dead tissues (current growth's production)] was taken as an approximation of ANPP. No samplings were conducted during 1979 to 1983 because of economic constraints. At harvesting time during 1984 to 1992, 30 randomly distributed, permanent plots $(0.5 \times 0.5 \mathrm{~m})$ were clipped to 30 to $50 \mathrm{~mm}$ stubble height on each disturbance type. Herbage was separated by species, except in the 1978 sampling when only total herbaceous standing crop was measured, and dried in a forced draft oven at $70^{\circ} \mathrm{C}$ until constant weight. Vegetation ANPP was then expressed on a dry weight basis. Within the desirable annual grass or forb group, a species was separated from the remaining total ANPP when its contribution to it was substantial. Previous to clipping from 1984 to 1990, plant cover of the herbaceous vegetation (i.e., cool- or warm-season perennial and annual grasses, and dicots) was also determined at a functional group scale on 20 out of the 30 randomly distributed, permanent plots $(0.5 \times 0.5 \mathrm{~m})$ per disturbance type following the canopy-cover method of Daubenmire (1959).

Aboveground standing crop was measured by species and plant functional groups, which were comprised of cool-season, $\mathrm{C}_{3}$ perennial grasses (CSPG); warm-season, $\mathrm{C}_{4}$ perennial grasses (WSPG), and cool-season, $\mathrm{C}_{3}$ annual grasses and forbs (CSAG+D). Annual forbs were not included in another functional group because they were just two plant species (i.e., M. minima and E. cicutarium), and their dry matter contribution to ANPP and plant cover were minimal. Estimates of ANPP were comprised from total standing crop harvests in all species. Total production was then calculated by summing up the individual plant functional group estimates. Table 1 shows the species composition of each functional group and its preference by grazing livestock. Root biomass was not collected or used in estimates of production.

\section{Statistical analysis}

At first, a multivariate analysis approach was conducted using the statistic of Wilks (Wilk's lambda) (Wilks, 1932). A repeated measures analysis was made for ANPP and plant cover between the study factors (functional groups $\mathrm{x}$ disturbance types) and years. Since there was an interaction between factors and years $(\mathrm{P}<0.05)$, each year was analyzed separately. Analyses were limited to annual means because seasonal analysis were not interpretable due to our inability to quantify the intra-seasonal impacts of carry-over soil water on ANPP, and herbaceous plant cover estimates. Standing crop and plant cover data were analyzed using two factorial ANOVA [functional group $\mathrm{x}$ disturbance types within each year]. When $\mathrm{F}$ tests were significant, means were always 
compared using the Tukey's test $(\mathrm{P}<0.05)$. The tests of Kolmogorov-Smirnov and Levene were used to evaluate normality and homoscedasticity assumptions, respectively. Because of this, data $(x)$ of standing crop needed to be transformed to $\log$ $(x+1)$ before analysis (Zar, 1996). Untransformed values are shown in Table 2 and Figures 4 and 5. Data were analyzed using the statistical software INFOSTAT (Di Rienzo et al., 2013).

\section{Results}

\section{Precipitation}

Annual precipitation across years showed a variation coefficient of $27.84 \%$ (e.g., see Figure 2). Average precipitation during the 1984-1992 study period $(473.91 \mathrm{~mm})$ was $11.9 \%$ above the long-term (1981-2011) average (417.6 $\mathrm{mm}=100 \%$ : Figure 2). As a percentage of the long-term average, annual precipitation ranged from 61.7 to $210.1 \%$ [257.5 (1989) to $877.3 \mathrm{~mm}$ (1984)]. In only 2 out of 9-study years (i.e., 1984 and 1992: Figure 2), each season precipitation exceeded the long-term average for that season. Means of long-term (1984-1992) seasonal precipitation were 101.2, 132, 90.4, and $127.8 \mathrm{~mm}$ for autumn, winter, spring and summer, respectively (Figure 2). Other precipitation features included (1) amounts of precipitation received in a single day ranged from $0 \mathrm{~mm}$ (no rainfall during November 1988) to $95.5 \mathrm{~mm}$ (28 Dec 1984), and (2) numbers of days with more than or equal to $5 \mathrm{~mm}$ rainfall fallen in a single day were 211 out of the 609 days with rainfall during the period 1984 to 1992 . Monthly pan evaporation was greater than monthly precipitation most of the times during 1984 to 1992 (Figure 3).

\section{Aboveground Net Primary Productivity}

\section{Total}

There was an interaction between disturbance types and years $(\mathrm{P}<0.05)$. Total ANPP was higher $(\mathrm{P}<0.05)$ in the Old Field 1 and/or Field 2 than in the (1) Overgrazing and (2) Control, Burning, and/or Shrub Control disturbance types during 1984 and 1985, 1987 and 1988, and from 1990 to 1992 (Figure 4). Annual net primary productivity was lower $(\mathrm{P}<0.05)$ in the Overgrazing disturbance than in the Control in 1985, 1988 and 1992 (Figure 4). The lowest ANPP within each disturbance type was achieved in 1986 and 1989 on all disturbance types, except for the Overgrazing disturbance type in 1986 and 1991 (Figure 4). Also, ANPP was most often lower ( $\mathrm{P}<0.05)$ in 1987, 1990 and 1991 than in 1984, 1985 and 1992 in the Control, Burning, Shrub Control and Old Field 1 disturbance types (Figure 4).

\section{Functional groups}

Cool-season perennial grasses showed the greatest $(\mathrm{P}<0.05)$ ANPP among functional groups in all disturbance types and study years (Figure 5). The greatest $(\mathrm{P}<0.05)$ ANPP of the CSPG occurred in 1984, 1985 and 1988 in the Old Field 1 disturbance type (Figure 5). ANPP in the cool-season perennial grass functional group was lowest $(\mathrm{P}<0.05)(1)$ in the Old Field 2 than on any other disturbance type in 1987, (2) in the Overgrazing than in the Old Field 2, Burning and Control disturbance types in 1989, and (3) in the Overgrazing than in the Old Fields 1 and 2 in 1991 (Figure 5). The warm- 
season perennial grasses showed their greatest $(\mathrm{P}<0.05)$ ANPP in the Old Field 2 than in any of the others disturbance types in all study years (Figure 5). Most of the times, the CSAG + D showed a greater $(\mathrm{P}<0.05)$ ANPP in the Old Field 1 and/or the Overgrazing than at the other disturbance types (e.g., OF1 and O in 1984; OF1 in 1985, 1987 and 1992; O in 1989: Figure 5).

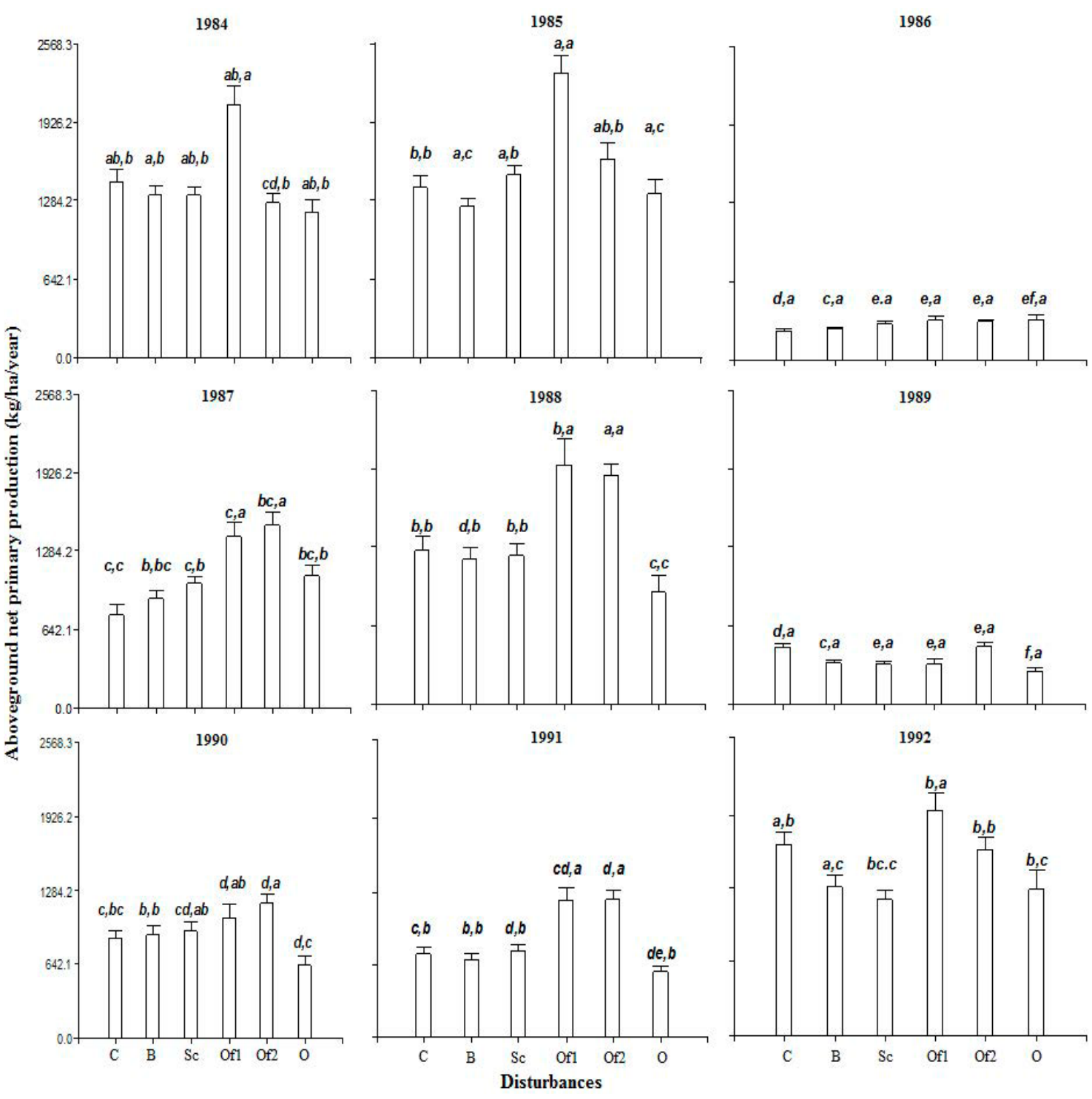

Figure 4. Total ANPP ( $\mathrm{kg} / \mathrm{ha}$ /year; $C S P G+W S P G+C S A G+$ Dicots $)$ in the different disturbance types $(C=$ Control, $B=$ Burning; Sc = Shrub Control; $O F 1=$ Old Field $1 ; O F 2=$ Old Field 2; O= Overgrazing) during the study years (1984 to 1992). Each histogram is the mean of $n=30$. Vertical bars are 1 SE of the means. Different letters to the left of the comma indicate significant differences $(P<0.05)$ among years within each disturbance type. Different letters to the right of the comma indicate significant differences $(P<0.05)$ among disturbance types within each year.

Analysis of the temporal ANPP dynamics revealed that relatively, the lowest values of ANPP occurred in 1986 and 1989 in all disturbance types on the three functional groups (Figure 5). 


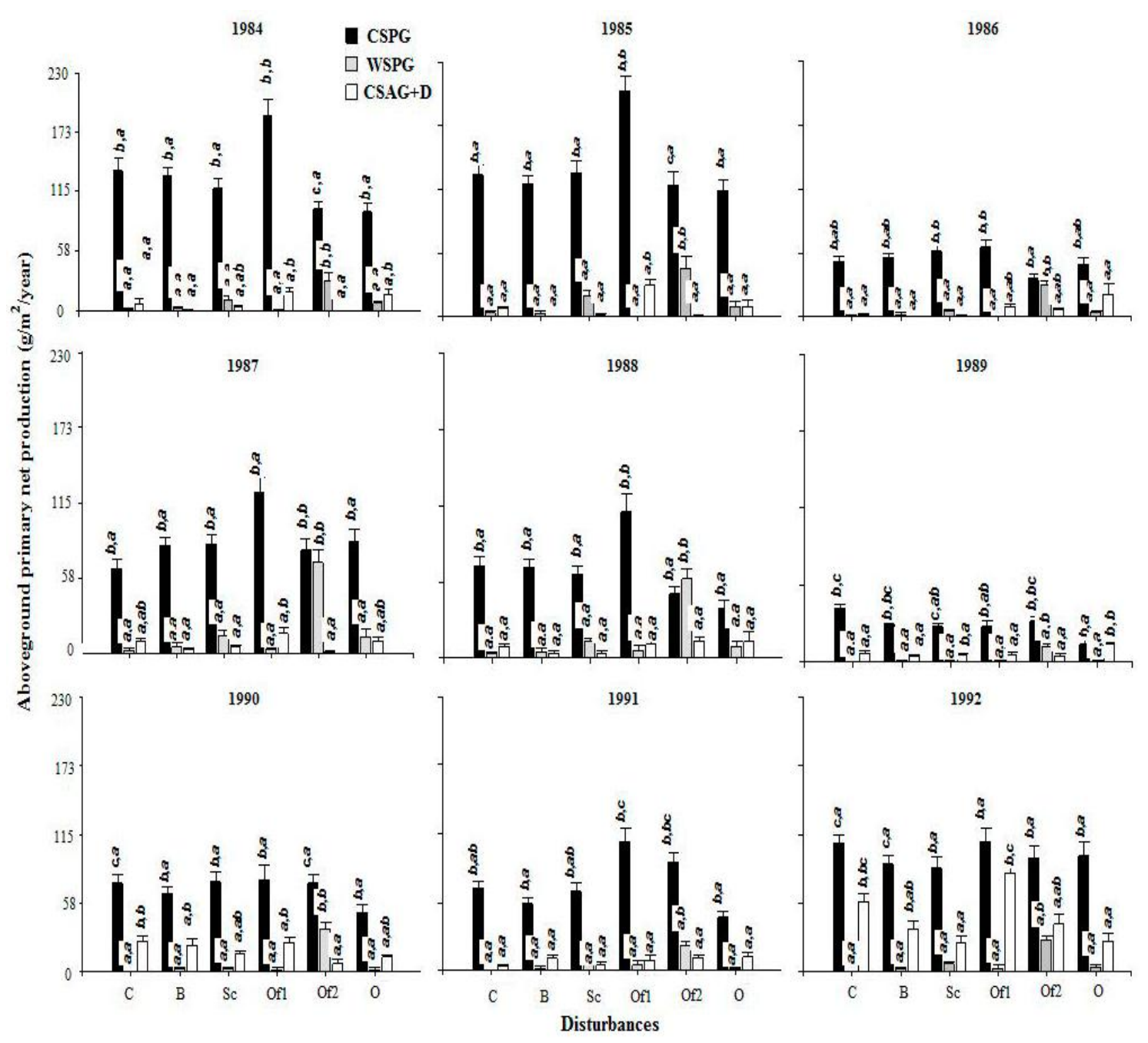

Figure 5. Aboveground net primary productivity $\left(\mathrm{gr} / \mathrm{m}^{2} /\right.$ year $)$ of the various functional groups $(C S P G=$ cool-season perennial grasses, $W S P G=$ warm-season perennial grasses, $C S A G+D=$ cool-season annual grasses + dicots $)$ in the different disturbance types $(C=C o n t r o l, B=$ Burning; Sc = Shrub Control; $O F 1=$ Old Field 1; OF2= Old Field 2; O= Overgrazing) during the study years (1984 to 1992). Each histogram is the mean of $n=30$. Vertical bars are 1 SE of the means. Different letters to the left of the comma indicate significant differences $(P<0.05)$ among functional groups within each disturbance type and study year. Different letters to the right of the comma indicate significant differences $(P<0.05)$ within each functional group in the various disturbance types on each study year.

\section{Plant Species}

The preferred $N$. clarazii and $P$. ligularis showed a greater $(\mathrm{P}<0.05)$ ANPP than the intermediate $P$. speciosa and the non-preferred A. ambigua and N. trichotoma in 23 out of 27 comparisons among these species in the Control, Burning and Shrub Control disturbance types (Table 2). In the Old Field 1, Old Field 2 and Overgrazing disturbance types, however, N. clarazii, P. ligularis, P. speciosa, A. ambigua and N. trichotoma showed a similar ( $\mathrm{P}>0.05)$ ANPP during 1984-1992 with only a few exceptions (Table 2). These exceptions were (1) A. ambigua, Old Field 1, 1984, (2) N. trichotoma, Old Field 1, 1992, and (3) N. clarazii, Old Field 2 in 1991, and Overgrazing in 1984. 
Table 2. Annual net primary productivity $(\mathrm{g} / \mathrm{m} 2)$ of various CSPG on different disturbance types from 1984 to 1992 . Each value represents the mean of $n=30$. Different letters indicate significant differences $(P<0.05)$ among plant species within each disturbance type and study year. Plant species are Nt=Nassella tenuis; $N c=$ Nassella clarazii $; P l=$ Poa ligularis; $P s=$ Pappostipa speciosa $;$ Aa = Amelichloa ambigua $;$ Ntr $=$ Nassella trichotoma. Disturbance types are C=Control; B= Burning; Sc=Shrub Control; OF1=Old Field 1; OF2=Old Field 2; O= Overgrazing.

\begin{tabular}{|c|c|c|c|c|c|c|c|c|c|c|}
\hline & Species & 1984 & 1985 & 1986 & 1987 & 1988 & 1989 & 1990 & 1991 & 1992 \\
\hline \multirow{6}{*}{$\mathrm{C}$} & $\mathrm{Nt}$ & $25.4 \pm 2.5 \mathrm{~b}$ & $30.6 \pm 3.2 \mathrm{~b}$ & $17.4 \pm 2.7 \mathrm{c}$ & $24.9 \pm 5.4 \mathrm{c}$ & $14.7 \pm 3.3 \mathrm{~b}$ & $10.5 \pm 1.8 \mathrm{~b}$ & $20.3 \pm 3.3 \mathrm{~b}$ & $23.1 \pm 3.5 \mathrm{~b}$ & $25.7 \pm 4.0 \mathrm{~b}$ \\
\hline & $\mathrm{Nc}$ & $58.2 \pm 9.9 \mathrm{c}$ & $51.2 \pm 7.6 \mathrm{c}$ & $13.0 \pm 2.0 \mathrm{bc}$ & $19.1 \pm 2.9 \mathrm{bc}$ & $28.8 \pm 4.4 \mathrm{c}$ & $11.1 \pm 1.9 \mathrm{~b}$ & $23.1 \pm 3.8 \mathrm{~b}$ & $23.1 \pm 3.5 \mathrm{~b}$ & $39.6 \pm 6.4 \mathrm{~b}$ \\
\hline & $\mathrm{Pl}$ & $31.9 \pm 5.9 \mathrm{~b}$ & $22.0 \pm 6.0 \mathrm{~b}$ & $9.3 \pm 1.8 \quad b$ & $9.0 \pm 2.2 \mathrm{ab}$ & $13.7 \pm 3.0 \mathrm{~b}$ & $10.2 \pm 2.2 \mathrm{~b}$ & $18.6 \pm 4.3 \mathrm{~b}$ & $13.6 \pm 2.7 b$ & $27.7 \pm 5.7 \mathrm{~b}$ \\
\hline & Ps & $1.1 \pm 0.5 \quad \mathrm{a}$ & $0.2 \pm 0.2 \quad \mathrm{a}$ & $0.1 \pm 0.1 \quad \mathrm{a}$ & $0.0 \pm 0.0 \quad \mathrm{a}$ & $0.4 \pm 0.3 \quad \mathrm{a}$ & $0.0 \pm 0.0 \mathrm{a}$ & $0.3 \pm 0.3 \quad \mathrm{a}$ & $1.5 \pm 1.5 \quad \mathrm{a}$ & $0.2 \pm 0.2 \quad \mathrm{a}$ \\
\hline & $\mathrm{Aa}$ & $0.0 \pm 0.0 \quad \mathrm{a}$ & $0.0 \pm 0.0 \mathrm{a}$ & $0.0 \pm 0.0 \quad \mathrm{a}$ & $0.0 \pm 0.0 \quad \mathrm{a}$ & $0.0 \pm 0.0 \quad \mathrm{a}$ & $0.0 \pm 0.0 \mathrm{a}$ & $0.0 \pm 0.0 \quad \mathrm{a}$ & $0.0 \pm 0.0 \quad \mathrm{a}$ & $0.0 \pm 0.0 \mathrm{a}$ \\
\hline & Ntr & $0.1 \pm 0.1 \quad \mathrm{a}$ & $0.8 \pm 0.8 \quad \mathrm{a}$ & $0.1 \pm 0.1 \quad \mathrm{a}$ & $0.3 \pm 0.3 \quad \mathrm{a}$ & $0.7 \pm 0.7 \quad \mathrm{a}$ & $0.7 \pm 0.7 \quad \mathrm{a}$ & $0.7 \pm 0.7 \quad \mathrm{a}$ & $0.9 \pm 0.9 \quad \mathrm{a}$ & $0.6 \pm 0.6 \quad \mathrm{a}$ \\
\hline & & & & & & & & & & \\
\hline \multirow{6}{*}{ B } & $\mathrm{Nt}$ & $25.7 \pm 3.3 \mathrm{~b}$ & $24.8 \pm 2.4 \mathrm{~b}$ & $12.9 \pm 1.9 \mathrm{~b}$ & $10.0 \pm 1.9 \mathrm{ab}$ & $5.6 \pm 1.0 \quad \mathrm{a}$ & $3.8 \pm 0.8 \mathrm{ab}$ & $5.3 \pm 1.3 \mathrm{a}$ & $5.4 \pm 1.6$ & $7.1 \pm 2.6 \quad \mathrm{a}$ \\
\hline & $\mathrm{Nc}$ & $46.6 \pm 5.8 \mathrm{c}$ & $42.3 \pm 4.3 \mathrm{c}$ & $15.2 \pm 2.1 \mathrm{~b}$ & $33.0 \pm 4.1 \mathrm{c}$ & $27.0 \pm 4.3 \mathrm{~b}$ & $6.7 \pm 1.0 \quad b c$ & $15.9 \pm 2.4 \mathrm{~b}$ & $19.2 \pm 2.8$ & $31.9 \pm 4.6 \mathrm{~b}$ \\
\hline & $\mathrm{Pl}$ & $24.3 \pm 4.8 \mathrm{~b}$ & $19.4 \pm 4.7 \mathrm{~b}$ & $11.6 \pm 2.2 \mathrm{~b}$ & $17.7 \pm 4.5 \mathrm{~b}$ & $21.3 \pm 5.0 \mathrm{~b}$ & $11.0 \pm 2.5 \mathrm{c}$ & $28.5 \pm 5.5 \mathrm{c}$ & $18.6 \pm 3.6$ & $35.4 \pm 6.4 \mathrm{~b}$ \\
\hline & Ps & $0.00 \pm 0.0 \mathrm{a}$ & $0.0 \pm 0.0 \quad \mathrm{a}$ & $0.0 \pm 0.0 \quad \mathrm{a}$ & $0.0 \pm 0.0 \quad \mathrm{a}$ & $0.0 \pm 0.0 \quad \mathrm{a}$ & $0.0 \pm 0.0 \quad \mathrm{a}$ & $0.0 \pm 0.0 \quad \mathrm{a}$ & $0.0 \pm 0.0$ & $0.0 \pm 0.0 \quad \mathrm{a}$ \\
\hline & $\mathrm{Aa}$ & $0.0 \pm 0.0 \quad \mathrm{a}$ & $0.0 \pm 0.0 \quad \mathrm{a}$ & $0.0 \pm 0.0 \quad \mathrm{a}$ & $0.0 \pm 0.0 \quad \mathrm{a}$ & $0.0 \pm 0.0 \quad \mathrm{a}$ & $0.0 \pm 0.0 \quad \mathrm{a}$ & $0.0 \pm 0.0 \quad \mathrm{a}$ & $0.0 \pm 0.0$ & $0.0 \pm 0.0 \quad \mathrm{a}$ \\
\hline & $\mathrm{Ntr}$ & $0.0 \pm 0.0 \quad \mathrm{a}$ & $0.0 \pm 0.0 \quad \mathrm{a}$ & $0.0 \pm 0.0 \quad \mathrm{a}$ & $0.0 \pm 0.0 \quad \mathrm{a}$ & $0.0 \pm 0.0 \quad \mathrm{a}$ & $0.0 \pm 0.0 \quad \mathrm{a}$ & $0.0 \pm 0.0 \quad \mathrm{a}$ & $0.0 \pm 0.0$ & $0.0 \pm 0.0 \quad \mathrm{ab}$ \\
\hline & & & & & & & & & & \\
\hline \multirow{6}{*}{ Sc } & $\mathrm{Nt}$ & $9.0 \pm 1.7 \quad \mathrm{a}$ & $17.4 \pm 2.7 \mathrm{~b}$ & $9.7 \pm 02.0 \mathrm{~b}$ & $10.4 \pm 2.6 \mathrm{ab}$ & $4.9 \pm 1.6 \mathrm{ab}$ & $1.5 \pm 0.5 \quad \mathrm{a}$ & $3.9 \pm 1.5 \quad \mathrm{a}$ & $3.7 \pm 1.0$ & $5.8 \pm 2.3 \quad b$ \\
\hline & $\mathrm{Nc}$ & $36.0 \pm 6.8 \mathrm{~b}$ & $30.2 \pm 4.7 \mathrm{bc}$ & $11.5 \pm 1.9 \mathrm{bc}$ & $19.5 \pm 3.8 \mathrm{bc}$ & $13.4 \pm 2.7 \mathrm{~b}$ & $3.2 \pm 1.0 \quad \mathrm{a}$ & $9.5 \pm 2.5 \quad \mathrm{a}$ & $11.8 \pm 3.0$ & $16.5 \pm 4.1 \mathrm{c}$ \\
\hline & $\mathrm{Pl}$ & $41.6 \pm 5.1 \mathrm{~b}$ & $33.0 \pm 4.8 \mathrm{c}$ & $16.5 \pm 2.4 \mathrm{c}$ & $28.6 \pm 4.6 \mathrm{c}$ & $28.3 \pm 5.5 \mathrm{c}$ & $13.0 \pm 2.1 \mathrm{~b}$ & $46.1 \pm 7.7 \mathrm{~b}$ & $37.8 \pm 5.8$ & $42.9 \pm 7.3 \mathrm{~b}$ \\
\hline & Ps & $0.00 \pm 0.0 \mathrm{a}$ & $0.0 \pm 0.0 \quad \mathrm{a}$ & $0.0 \pm 0.0 \quad \mathrm{a}$ & $0.0 \pm 0.0 \quad \mathrm{a}$ & $0.0 \pm 0.0 \quad \mathrm{a}$ & $0.0 \pm 0.0 \quad \mathrm{a}$ & $0.0 \pm 0.0 \quad \mathrm{a}$ & $0.0 \pm 0.0$ & $0.0 \pm 0.0 \quad \mathrm{a}$ \\
\hline & $\mathrm{Aa}$ & $0.0 \pm 0.0 \quad \mathrm{a}$ & $0.0 \pm 0.0 \quad \mathrm{a}$ & $0.0 \pm 0.0 \quad \mathrm{a}$ & $0.0 \pm 0.0 \quad \mathrm{a}$ & $0.0 \pm 0.0 \quad \mathrm{a}$ & $0.0 \pm 0.0 \quad \mathrm{a}$ & $0.0 \pm 0.0 \quad \mathrm{a}$ & $0.0 \pm 0.0$ & $0.0 \pm 0.0 \quad \mathrm{a}$ \\
\hline & $\mathrm{Ntr}$ & $3.3 \pm 2.6 \quad \mathrm{a}$ & $3.7 \pm 3.5 \quad \mathrm{a}$ & $0.4 \pm 0.4 \quad \mathrm{a}$ & $0.8 \pm 0.7 \quad \mathrm{a}$ & $1.1 \pm 0.9 \quad \mathrm{a}$ & $0.6 \pm 0.3 \quad \mathrm{a}$ & $0.6 \pm 0.3 \quad \mathrm{a}$ & $1.0 \pm 0.8$ & $2.0 \pm 1.8 \quad \mathrm{a}$ \\
\hline & & & & & & & & & & \\
\hline \multirow{6}{*}{$\begin{array}{c}\mathrm{O} \\
\mathrm{F} \\
1\end{array}$} & $\mathrm{Nt}$ & $80.2 \pm 14.0$ & $105.2 \pm 19.7 \mathrm{~b}$ & $34.6 \pm 6.9 \mathrm{~b}$ & $53.6 \pm 10.2 \mathrm{~b}$ & $36.5 \pm 6.8 \mathrm{~b}$ & $12.6 \pm 3.4 \mathrm{~b}$ & $27.9 \pm 6.0 \quad b$ & $45.0 \pm 9.7$ & $45.3 \pm 8.6 \mathrm{~b}$ \\
\hline & $\mathrm{Nc}$ & $5.5 \pm 1.7$ & $11.4 \pm 4.9 \quad \mathrm{a}$ & $5.3 \pm 1.8 \quad \mathrm{a}$ & $15.3 \pm 5.4 \quad \mathrm{a}$ & $13.1 \pm 4.5 \mathrm{a}$ & $1.5 \pm 0.6 \quad \mathrm{a}$ & $6.6 \pm 2.1$ & $12.9 \pm 4.2$ & $18.5 \pm 5.7 \mathrm{a}$ \\
\hline & $\mathrm{Pl}$ & $6.4 \pm 3.7$ & $6.6 \pm 3.3$ & $4.6 \pm 2.3 \quad \mathrm{a}$ & $8.2 \pm 03.6 \quad \mathrm{a}$ & $9.9 \pm 4.0 \quad \mathrm{a}$ & $2.7 \pm 1.3 \quad \mathrm{a}$ & $9.5 \pm 4.1$ & $19.8 \pm 8.1$ & $21.5 \pm 8.6 \mathrm{a}$ \\
\hline & Ps & $0.0 \pm 0.0$ & $0.0 \pm 0.0$ & $0.0 \pm 0.0 \quad \mathrm{a}$ & $0.0 \pm 0.0 \quad \mathrm{a}$ & $0.0 \pm 0.0 \quad \mathrm{a}$ & $0.0 \pm 0.0 \quad \mathrm{a}$ & $0.0 \pm 0.0$ & $0.0 \pm 0.0$ & $0.0 \pm 0.0 \quad \mathrm{a}$ \\
\hline & $\mathrm{Aa}$ & $44.1 \pm 8.8$ & $28.4 \pm 8.5 \quad \mathrm{a}$ & $6.9 \pm 2.1 \quad \mathrm{a}$ & $17.2 \pm 6.5 \mathrm{a}$ & $5.0 \pm 2.6 \quad \mathrm{a}$ & $2.7 \pm 2.0 \quad \mathrm{a}$ & $18.7 \pm 11.0 \mathrm{ab}$ & $6.9 \pm 3.9$ & $9.7 \pm 3.8 \quad \mathrm{a}$ \\
\hline & $\mathrm{Ntr}$ & $0.0 \pm 0.0$ & $0.0 \pm 0.0$ & $0.3 \pm 0.3 \quad \mathrm{a}$ & $0.0 \pm 0.0 \quad \mathrm{a}$ & $0.0 \pm 0.0 \quad \mathrm{a}$ & $0.0 \pm 0.0 \quad \mathrm{a}$ & $0.0 \pm 0.0$ & $0.0 \pm 0.0$ & $0.0 \pm 0.0 \quad b$ \\
\hline
\end{tabular}




\begin{tabular}{|c|c|c|c|c|c|c|c|c|c|c|}
\hline \multirow{6}{*}{$\begin{array}{l}\mathrm{O} \\
\mathrm{F} \\
2\end{array}$} & $\mathrm{Nt}$ & $69.4 \pm 8.4 \mathrm{~b}$ & $57.2 \pm 8.2 \mathrm{~b}$ & $19.3 \pm 3.0 \mathrm{~b}$ & $36.9 \pm 6.8 \mathrm{~b}$ & $24.0 \pm 4.7 \mathrm{~b}$ & $22.3 \pm 3.7 b$ & $51.3 \pm 7.2 \mathrm{~b}$ & $49.2 \pm 7.2$ & $35.5 \pm 5.8 \mathrm{~b}$ \\
\hline & $\mathrm{Nc}$ & $4.0 \pm 1.8 \quad \mathrm{a}$ & $4.6 \pm 1.9 \quad \mathrm{a}$ & $3.3 \pm 1.2 \mathrm{a}$ & $5.2 \pm 2.0 \quad \mathrm{a}$ & $6.5 \pm 2.9 \mathrm{a}$ & $3.4 \pm 1.1 \quad \mathrm{a}$ & $7.4 \pm 2.6 \quad \mathrm{a}$ & $18.4 \pm 5.3$ & $27.8 \pm 8.2 \mathrm{a}$ \\
\hline & $\mathrm{Pl}$ & $0.0 \pm 0.0 \quad \mathrm{a}$ & $0.0 \pm 0.0 \quad \mathrm{a}$ & $0.0 \pm 0.0 \quad \mathrm{a}$ & $0.0 \pm 0.0 \quad \mathrm{a}$ & $0.0 \pm 0.0 \quad \mathrm{a}$ & $0.0 \pm 0.0 \quad \mathrm{a}$ & $0.4 \pm 0.3 \quad \mathrm{a}$ & $1.4 \pm 1.0$ & $3.0 \pm 2.1 \quad \mathrm{a}$ \\
\hline & Ps & $0.0 \pm 0.0 \quad \mathrm{a}$ & $0.0 \pm 0.0 \quad \mathrm{a}$ & $0.0 \pm 0.0 \quad \mathrm{a}$ & $0.0 \pm 0.0 \quad \mathrm{a}$ & $0.0 \pm 0.0 \quad \mathrm{a}$ & $0.0 \pm 0.0 \quad \mathrm{a}$ & $0.0 \pm 0.0 \quad \mathrm{a}$ & $0.0 \pm 0.0$ & $0.0 \pm 0.0 \quad \mathrm{a}$ \\
\hline & $\mathrm{Aa}$ & $0.2 \pm 0.2 \quad \mathrm{a}$ & $0.0 \pm 0.0 \quad \mathrm{a}$ & $0.0 \pm 0.0 \quad \mathrm{a}$ & $0.0 \pm 0.0 \quad \mathrm{a}$ & $0.0 \pm 0.0 \quad \mathrm{a}$ & $0.0 \pm 0.0 \quad \mathrm{a}$ & $0.0 \pm 0.0$ & $0.0 \pm 0.0$ & $0.0 \pm 0.0 \quad \mathrm{a}$ \\
\hline & $\mathrm{Ntr}$ & $0.0 \pm 0.0 \quad \mathrm{a}$ & $0.0 \pm 0.0 \quad \mathrm{a}$ & $0.0 \pm 0.0 \quad \mathrm{a}$ & $0.0 \pm 0.0 \quad \mathrm{a}$ & $0.0 \pm 0.0 \quad \mathrm{a}$ & $0.0 \pm 0.0 \quad \mathrm{a}$ & $0.0 \pm 0.0 \quad \mathrm{a}$ & $0.0 \pm 0.0$ & $0.0 \pm 0.0 \quad \mathrm{a}$ \\
\hline & $\mathrm{Nt}$ & $287+28 c$ & $274+48 b$ & $87+18 \mathrm{~h}$ & $111+27 \mathrm{~h}$ & $42+119$ & $12+04 \mathrm{~h}$ & $32+119$ & $25+110$ & $162+764$ \\
\hline \multirow{5}{*}{$\mathrm{O}$} & $\mathrm{Nc}$ & $8.1 \pm 1.8 \mathrm{~b}$ & $7.7 \pm 2.7 \mathrm{a}$ & $2.1 \pm 0.7 \mathrm{a}$ & $4.1 \pm 1.3 \mathrm{a}$ & $3.3 \pm 1.5 \mathrm{a}$ & $1.0 \pm 0.5 \mathrm{ab}$ & $3.5 \pm 2.1 \mathrm{a}$ & $2.7 \pm 1.7 \mathrm{a}$ & $6.6 \pm 4.0 \mathrm{ab}$ \\
\hline & $\mathrm{Pl}$ & $1.5 \pm 1.0 \mathrm{~b} \mathrm{a}$ & $1.1 \pm 1.0 \mathrm{a}$ & $1.3 \pm 1.3 \mathrm{a}$ & $1.4 \pm 1.4 \mathrm{a}$ & $2.1 \pm 1.9 \mathrm{a}$ & $0.5 \pm 0.3 \mathrm{ab}$ & $5.3 \pm 3.6 \mathrm{a}$ & $3.7 \pm 2.3 \mathrm{a}$ & $3.5 \pm 2.5 \mathrm{ab}$ \\
\hline & Ps & $0.0 \pm 0.0 \mathrm{a}$ & $0.0 \pm 0.0 \mathrm{a}$ & $0.0 \pm 0.0 \mathrm{a}$ & $0.0 \pm 0.0 \mathrm{a}$ & $0.0 \pm 0.0 \mathrm{a}$ & $0.0 \pm 0.0 \mathrm{a}$ & $0.0 \pm 0.0 \mathrm{a}$ & $0.0 \pm 0.0 \mathrm{a}$ & $0.0 \pm 0.0 \mathrm{a}$ \\
\hline & $\mathrm{Aa}$ & $0.0 \pm 0.0 \mathrm{a}$ & $0.0 \pm 0.0 \mathrm{a}$ & $0.0 \pm 0.0 \mathrm{a}$ & $0.0 \pm 0.0 \mathrm{a}$ & $0.0 \pm 0.0 \mathrm{a}$ & $0.0 \pm 0.0 \mathrm{a}$ & $0.0 \pm 0.0 \mathrm{a}$ & $0.0 \pm 0.0 \mathrm{a}$ & $0.0 \pm 0.0 \quad \mathrm{a}$ \\
\hline & $\mathrm{Ntr}$ & $3.6 \pm 2.1 \mathrm{a}$ & $6.9 \pm 4.5 \mathrm{a}$ & $0.6 \pm 0.4 \mathrm{a}$ & $1.4 \pm 1.4 \mathrm{a}$ & $0.4 \pm 0.4 \mathrm{a}$ & $0.0 \pm 0.0 \mathrm{a}$ & $0.9 \pm 0.9 \mathrm{a}$ & $0.00 \pm 0.0$ & $1.7 \pm 1.2 \mathrm{ab}$ \\
\hline
\end{tabular}


Nassella clarazii showed a similar $(\mathrm{P}>0.05)$ or greater $(\mathrm{P}<0.05)$ ANPP than $P$. ligularis during all years and disturbance types (Table 2). The only exceptions occurred in the Shrub Control disturbance type during 1988 to 1992, and the Burning disturbance type in 1990 , where $P$. ligularis had a greater $(\mathrm{P}<0.05)$ ANPP than $N$. clarazii (Table 2). Nassella tenuis showed the greatest $(\mathrm{P}<0.05)$ contribution among all six study species in the Old Field 1, Old Field 2 and Overgrazing disturbance types except in 7 (Old Field 1: 1990; Old Field 2: 1991 and Overgrazing: 1988 to 1992) out of 27 comparisons (Table 2).

\section{Plant cover}

\section{Plant Functional Groups}

Except in the Old Field 2 from 1987 to 1990, the CSPG showed a greater $(\mathrm{P}<0.05)$ percentage cover than the other two functional groups in all disturbance types and years (Figure 6). In 1988, 1989 and 1990, the WSPG showed a greater $(\mathrm{P}<0.05)$ percentage plant cover than the CSPG at the Old Field 2 (Figure 6). In 1984 and from 1987 to 1990 , percentage plant cover was greater $(\mathrm{P}<0.05)$ on the CSAG $+\mathrm{D}$ than on the WSPG $(\mathrm{P}<0.05)$ in the Old Field 1 and Overgrazing disturbance types (Figure 6). At these disturbance types and in the Control, the CSAG $+\mathrm{D}$ also showed a greater $(\mathrm{P}<0.05)$ percentage cover than the WSPG from 1988 to 1990 (Figure 6).

\section{Disturbance types}

Percentage plant cover of CSPG was lower $(\mathrm{P}<0.05)$ in the Old Field 2 and Overgrazing disturbance types than in Control in all study years (Figure 6). Percentage plant cover of the CSPG was greater $(\mathrm{P}<0.05)$ at the Shrub Control than at any of the other disturbance types in 1987 (Figure 6). Cool-season perennial grasses showed a similar $(\mathrm{P}>0.05)$ percentage plant cover at the Old Field 1 and Overgrazing disturbance types from 1984 to 1990 (Figure 6). Warm-season perennial grasses showed the greatest $(\mathrm{P}<0.05)$ percentage cover in the Old Field 2 that at any of the other disturbance types from 1984 to 1990 (Figure 6). Percentage cover of this functional group was greater $(\mathrm{P}>0.05)$ in the Shrub Control than in the Old Field 1 disturbance type during the whole study period (1984 to 1990) (Figure 6). From 1986 to 1989, percentage cover of WSPG was also lower $(\mathrm{P}<0.05)$ in the Overgrazing than in the Shrub Control disturbance type (Figure 6). Percentage cover of the CSAG $+\mathrm{D}$ was greater $(\mathrm{P}<0.05)$ at the Old Field 1 than at the (1) other disturbance types (but the Old Field 2 disturbance type) in 1989, (2) Shrub Control and Burning disturbance types in 1987 and 1989, and (3) Burning disturbance type in 1988 (Figure 6). Also, percentage cover of this functional group was similar $(\mathrm{P}>0.05)$ at the Old Field 1, Old Field 2 and Overgrazing disturbance types from 1987 to 1989, and greatest $(\mathrm{P}<0.05)$ at the Old Field 2 than at any other disturbance type in 1990 (Figure 6).

\section{Discussion}

Lowest values of ANPP were achieved at the lowest values of annual precipitation in all study disturbance types. This indicates that annual precipitation would be relatively more important than disturbance type in determining ANPP in the study functional groups. 


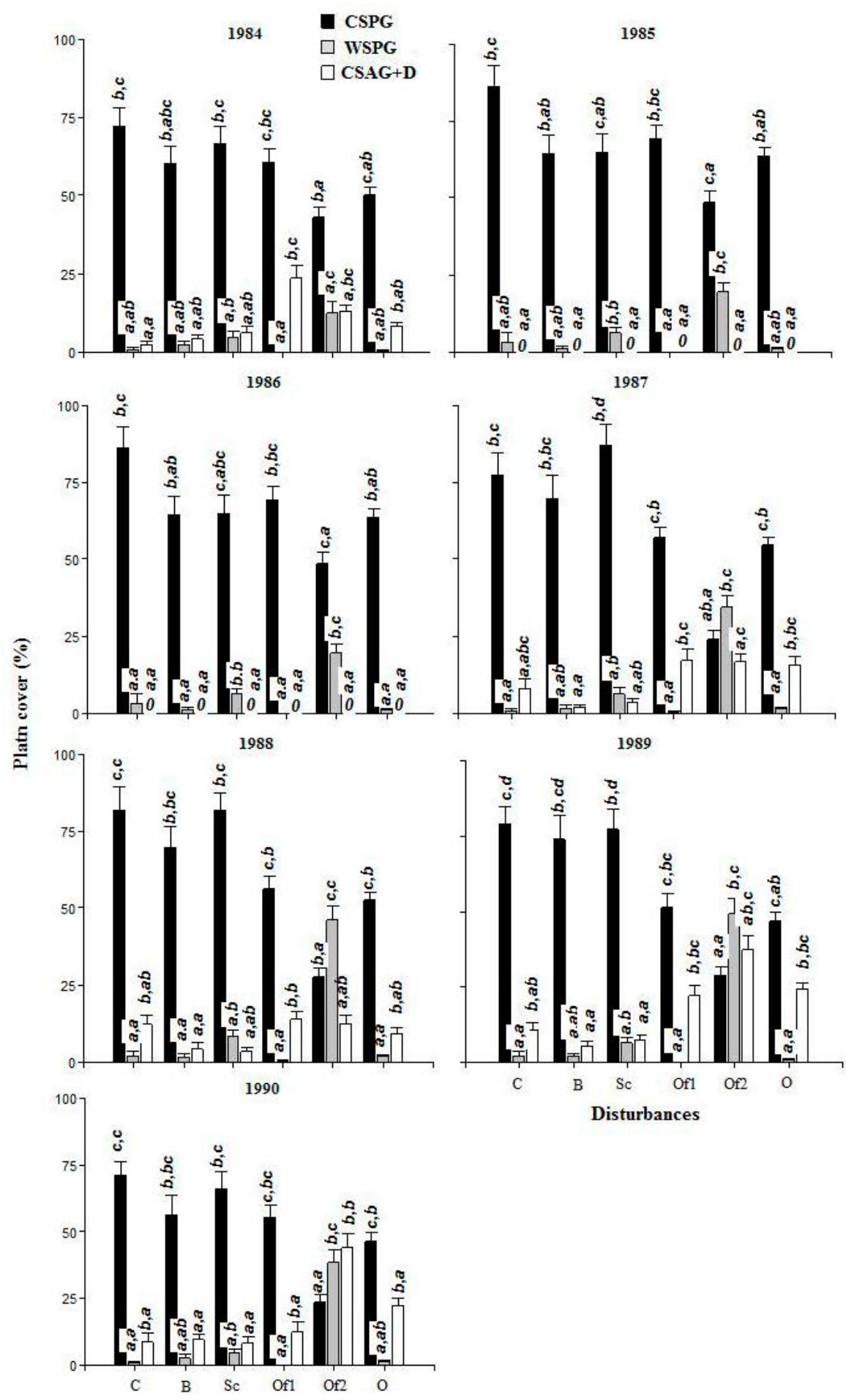

Figure 6. Total herbaceous plant cover (\%) of the various functional groups (CSPG $=$ coolseason perennial grasses, $W S P G=$ warm-season perennial grasses, $C S A G+D=$ cool-season annual grasses + dicots) in the different disturbance types ( $C=C$ Control, $B=B u r n i n g ; ~ S c=$ Shrub Control; OF1= Old Field 1; OF2= Old Field 2; O= Overgrazing) during the study years (1984 to 1992). Each histogram is the mean of $n=30$. Vertical bars are 1 SE of the means. Different letters to the right of the comma indicate significant differences $(P<0.05)$ among disturbance types within each functional group and study year. Different letters to the left of the comma indicate significant differences $(P<0.05)$ among functional groups within each disturbance type and study year. 


\section{Total Annual Net Primary Productivity}

The lowest and highest total annual herbaceous ANPP were obtained in the Burned (mean $=967 \mathrm{~kg} \mathrm{ha}^{-1} \mathrm{yr}^{-1}, 52 \%$ of control) and Old Field 2 (mean=3804 kg ha-1 $\mathrm{yr}^{-1}, 203 \%$ of control) disturbances, respectively, one year after treatments (data not shown). Bartos et al. (1994) and Cook et al. (1994) reported similar results. Other studies have reported an increased forage production after mechanical disturbances in rangelands (Griffith et al., 1985), very likely because of the release of plant nutrients as a result of soil disturbance (Haferkamp et al., 1993). This might be because total ANPP was higher in the Old Field 1 and/or Old Field 2 than in the other disturbance types during most of the study years.

The only years where all disturbance types showed a similar, low ANPP were 1986 and 1987. These years were when monthly precipitation most of the months, and total annual precipitation, were below the long-term average. In the other years, which showed a similar or higher annual precipitation than the long-term average, there were significant differences among disturbance types to a greater or lower extent. This indicates that the amount of annual precipitation imposed a greater constraint than disturbance type to ANPP. A myriad of studies have shown decreases in total ANPP with decreases in total annual precipitation (Walker, 1999), emphasizing that precipitation is a major determinant of the structure and function of terrestrial ecosystems (Webb et al., 1983).

In some years $(1985,1988,1992)$, total annual net primary productivity was lower in the Overgrazing than in the Control disturbance type. Other studies have also shown a decrease in ANPP on grazed than ungrazed perennial rangeland grasses (Busso and Richards, 1995).

During 1984 to 1992, total ANPP ranged from 261.2 (Control, 1986) to 2481.21 (Old Field 1, 1985) $\mathrm{kg} \mathrm{ha}^{-1} \mathrm{yr}^{-1}$ (Figure 4). These values are within the range reported by Digiuni (1983), Cano (1988) and Fresnillo Fedorenko et al. (1991) for rangelands within the Phytogeographical Province of the Espinal, Argentina. Total ANPP was lower in the Control than in the (1) Old Field 1 disturbance in 1984-1988 and 1991, and (2) Old Field 2 disturbance in 1986-1988 and 1991 (Figure 4). Once again, nutrient release as a result of soil disturbance in Old Fields 1 and 2 might have contributed to the increased ANPP in both study Old Fields than in the Control (Haferkamp et al., 1993).

The Control and Shrub Control disturbances had a similar total ANPP between 19841992, except in 1989 and 1992, when it was greater in the Control than in the Shrub Control disturbance. Meyer and Bovey (1985) also reported that dry weight of grasses on a rangeland pasture in east-central Texas treated with 2,4,5-T was similar to that in untreated areas 4-17 month after treatment. In 1989 and 1990, total ANPP was greater in the Control than in the Overgrazing treatment. Increased grazing intensity has already been shown to decrease herbaceous standing crop in several arid or semi-arid ecosystems of North and South America, and Australia (Archer and Smeins, 1991).

As a result of overgrazing, open, nude patches can appear between vegetation patches in arid and semiarid rangelands of central Argentina. These open patches, where colonies of the herbivore vizcacha (Lagostomus maximus, Chinchillidae) might establish (Bontti et al., 1999), are ideal for the germination, establishment, and substantial dry matter production of mostly Medicago minima and Erodium cicutarium in wet years (Fresnillo Fedorenko et al., 1991). This might be one of the major reasons to explain why forage production of the CSAG+D was greater in the Old Field 1 and 
Overgrazing than in the remaining disturbance types during most of the years above the long-term average annual precipitation.

\section{Functional groups}

The greatest productivity among the study functional groups was that on CSPG in all disturbance types and study years. Giorgetti et al. (1999) reported that plant cover of CSPG is dominant in well-managed rangelands of arid, southwestern Buenos Aires, Argentina. The cattle production industry in $75 \%$ of continental Argentina, characterized by arid and semiarid areas, is based upon grazing of native vegetation (Fernández and Busso, 1999). Unfortunately, most of these areas have been exposed to grazing and fire mismanagement, resulting in shrub enchroachment and the local disappearance of acceptable perennial forage grasses for cattle grazing (Fernández and Busso, 1999). As a result, rangelands of central Argentina have few warm-season, native perennial grasses that are acceptable forages to grazing livestock (i.e., Pappophorum vaginatum; Busso et al., 2004). This helps to explain the low ANPP of the WSPG in most disturbance types and study years. The introduction of WSPG which are a food constraint for grazing cattle and sheep constitutes an unsolved, critical challenge to date in arid, northeastern rangelands of Patagonia (Torres et al., 2013). The great contribution of CSAG to total ANPP in the Old Field 1 and Overgrazing disturbance types is coincident with the state-and-transition model reported by Distel and Bóo (1996). These authors stated that annuals will take over the open, nude surface areas left between vegetated patches when range management is characterized by very high grazing intensities and fire mismanagement. LLorens (1995) also reported that annuals occur on highly disturbed sites on a variety of soil types.

\section{Plant Species}

The combined contribution of $N$. clarazii and P. ligularis to total ANPP was less or greater than 24 or $44 \%$ in the Overgrazing or Control treatment, respectively, during 1984-1992 (data not shown). Bóo et al. (1993) reported that these two grazing tolerant, species (Saint Pierre et al., 2004 a,b; Gittins, 2011) are the most highly preferred by cattle in semi-arid rangelands of central Argentina, and tend to disappear from the pastures with heavy grazing.

Non-preferred perennial grasses (Table 1) were mostly confined to the Old Field1 (e.g. A. ambigua: Table 2) and Overgrazing (e.g., N. trichotoma: Table 2) disturbance types. Species of this group, namely A. ambigua, A. brachychaeta and N. trichotoma (Table 1) are indicative of previous grazing mismanagement conducive to rangeland deterioration (Cano, 1988). A greater ANPP of A. ambigua in the Old Field 1 was probably due to the greater proximity of this site to a water source for cattle, causing a more severe and continuous grazing.

Nassella clarazzi and P. ligularis are among the most competitive native perennial grasses in the study region (Saint Pierre et al., 2004b; Ithurrart, 2014). It has been reported that non-preferred, native perennial grasses (e.g., A. ambigua), avoided by grazing animals, have a higher tissue $\mathrm{C} / \mathrm{N}$ and lignin/ $\mathrm{N}$ ratios than preferred, native perennial grasses (e.g., Nassella clarazzi and P. ligularis) in central Argentina (Moretto et al., 2001). The similar N concentration on green leaves of P. ligularis than on those of N. clarazii (Saint Pierre et al., 2004b; Moretto et al., 2013) and the lower lignin content on leaf cells of $P$. ligularis than on those of $N$. clarazii (Moretto et al., 2001) 
suggests that grazing livestock might have a relatively greater preference of $P$. ligularis than $N$. clarazii. This might help to explain the greater ANPP in $N$. clarazii than $P$. ligularis most of the times. Both species have been shown to be very competitive for soil resources (Saint Pierre et al., 2004b; Ithurrart, 2014). However, which species is more competitive than the other one has not yet been determined.

Cultivation over 25 years must have eliminated the original vegetation in the open shrubland with a continuous herbaceous layer of $N$. tenuis. After abandonment, successful seed germination and establishment from existing seeds of $N$. tenuis in areas with low interference from surrounding vegetation (Distel et al., 1992), and the very high vegetative reproduction reported for this species (Busso et al., 1993), may help to explain its persistence and high contribution to total herbaceous standing crop in both Old Field treatments.

The Burning disturbance may have been severe enough to negatively affect intermediate (i.e., P. speciosa, Table 1) and not-preferred (A. ambigua and $N$. trichotoma) perennial grasses which were absent during 1984-1992 (Table 2). Bóo et al. (1996) reported very high mortality rates in $P$. speciosa (previously $S$. speciosa) after a very severe wildfire during summer time. These authors attributed this response to the fact that $P$. speciosa is not readily consumed by cattle, and accumulates old growth which may explain the high burning temperatures. A similar response might be expected with the other grass species of these groups because they may only be grazed when better forage is not available (Cano, 1988), which would also allow for old growth accumulation. Species such as P. ligularis, $N$. clarazii and $N$. tenuis have had lower mortality rates than $P$. speciosa after a severe wildfire partly because they are readily grazed by cattle and do not accumulate as much old growth around the growing points (Bóo et al., 1996).

Cool-season annual grasses + Dicots were either absent or contributed up to approximately 50\% of total ANPP in 1989 (Overgrazing disturbance type) (Figure 5). The contribution of the desirable annual grasses or dicots to total ANPP was usually higher in the Overgrazing or Old Field 1 disturbance type than in others. Annual grasses have been shown previously to increase with overgrazing in semi-arid rangelands of central Argentina (Cano, 1988), and with soil disturbance in South Dakota (Gartner et al., 1986). Our ANPP values for M. minima and E. cicutarium during 1984-1992 in all treatments (Figure 5) are lower than those reported by Fresnillo Fedorenko et al. (1991) on overgrazed and ungrazed sites of the Phytogeographical Province of the Espinal, Argentina. Medicago minima, and to a lesser extent E. cicutarium, however, can become major forages and an important complement of the herbivorous diet under conditions of aridity and overgrazing (Fresnillo Fedorenko et al., 1991).

\section{Herbaceous plant cover}

\section{Functional groups}

We showed that contribution to total herbaceous plant cover was greater on CSPG than on WSPG and CSAG+D in most of the disturbance types and study years. Volesky et al. (2010) reported that warm-season grasses usually have less total annual production because they do not actively grow during as much of the growing season as do coolseason grasses in Nebraska. These authors also considered that warm-season grasses cannot be made to grow at all during early spring and fall when soil and air temperatures are cool. This agrees with the shorter growing cycle on WSPG than on 
CSPG in rangelands of central Argentina. The total growth cycle is from late-February (i.e., late summer) to mid-December (i.e., late spring) for CSPG, and from mid-spring (i.e., November) to late fall (i.e., May) for WSPG (Giorgetti et al., 2000).

Most of the times, total herbaceous plant cover of CSAG+D was greater than that of WSPG at the Old Field 1 and Overgrazing disturbance types. These results are similar to those reported by Digiuni (1983) who showed that desirable annual grasses [e.g., Bromus catharticus Vahl; B. mollis L.; Hordeum murinum L.; Lolium multiflorum Lam.; S. barbatus; Vulpia megalura (Nutt.) Rydb.] or forbs (e.g., E. cicutarium; $M$. minima) contributed up to $45 \%$ or $22 \%$, respectively, of herbaceous standing crop on overgrazed or abandoned fields, respectively. Annual grasses and dicots have been shown previously to increase with overgrazing in semi-arid rangelands of central Argentina (Cano, 1988; Distel and Bóo, 1996), and with soil disturbance in the Great Basin (Klemmedson and Smith, 1964) and South Dakota (Gartner et al., 1986). Fresnillo Fedorenko et al. (1991) showed that the dry matter production of dicots (e.g., M. minima, E. cicutarium, and species of the genus Plantago, Herniaria, Capsella and Geranium) was greater on grazed than on ungrazed sites in rangelands of central Argentina. Species of this group (i.e., CSAG+D) are indicative of previous grazing mismanagement conducive to rangeland deterioration (Cano, 1988). However, the legume M. minima and the Geraniaceae E. cicutarium can become major forages and an important complement of the herbivorous diet under conditions of overgrazing in years when annual precipitation exceeds the long-term average (Fresnillo Fedorenko et al., 1991). This is similar to that reported by White (1985) and Whisenant (1990) that the standing crop of desirable annuals does positively correlate with annual rainfall.

\section{Disturbance types}

Plant cover of CSPG was greatest in the Shrub Control disturbance type in 1987. Similarly, plant cover of WSPG was greater at the Shrub Control than at the Old Field 1 (1984-1990) and Overgrazing (1986-1989) disturbance types. Bonan (2002) reported that control of sagebrush is a proven method to increase forage for livestock in the semiarid intermountain west of the United States. Sturges (1993) showed that herbicide application virtually eliminated sagebrush throughout 20 years; productivity of grasses more than double compared with untreated sites for the first three years following treatment, and was still higher than untreated sites 10 to 17 years following shrub removal. Increases from 5 to 15 times in desirable perennial grasses after herbicide application to shrubs have also been reported by Baker et al. (1980).

Our results are similar to those of Tizón et al (2010). These authors reported the convenience of using controlled fires for reversing processes of scrub formation to states with more diverse and productive grassland communities. Using a fire frequency of 7 to 8 years, Tizón et al. (2010) demonstrated a proliferation of palatable perennial grasses at a study site of the Caldén Phytogeographical District in central Argentina. A characteristic palatable perennial grass in the region, Nassella clarazii, showed the greatest cover when the controlled-fire frequency was from 7 to 8 years. Their results showed that use of intermediate controlled-fire frequencies would favor the aerial cover of palatable perennial grasses in states that are most useful for a sustainable cattle production.

Plant cover of CSAG+D at the Old Field 1 was either greater than that at (a) any other disturbance type (but OF2) in 1989, and (b) the Shrub Control and Burning disturbance types in 1987, 1988 and 1989, or similar to that in the OF2 and Overgrazing 
disturbance types from 1987 to 1989. These results are similar to those of Distel and Bóo (1996), who reported the appearance of annual grasses and dicots under extreme conditions of land degradation in the Phytogeographical Province of the Espinal, namely 'The Caldenal', in central Argentina as a result of grazing mismanagement.

Plant cover of the WSPG (1984 to 1990) and CSAG+D (1990) were the greatest at the Old Field 2 disturbance type. Du et al. (2007) demonstrated that as community biomass increased with time from farmland abandonment, various soil nutrients (e.g., P, total N, organic matter, nitrate nitrogen) also increased at the same time. Thus, it is possible that soil nutrient increases with time from farmland abandonment (i.e., Old Field 2) might have contributed to increase plant cover of the WSPG and the CSAG+D.

\section{Conclusions}

In most study years (1984 to 1992), values for total (Figure 4) and functional-group ANPP (Figure 5), and total plant cover (Figure 6) were disturbance-type dependent. This emphasizes the importance of the previous-land history in determining the subsequent values for those study variables. However, lowest values of total ANPP were achieved in years with the lowest annual precipitation in all disturbance types. This indicates that annual precipitation would be more important than disturbance type in determining ANPP in the study functional groups.

Cool-season perennial grasses made the greatest $(\mathrm{P}<0.05)$ contribution to ANPP and plant cover (Figures 5 and 6) compared with that of the other two functional groups in all disturbance groups and years.

In more than $55 \%$ of the study years, ANPP of CSAG + D was greater $(\mathrm{P}<0.05)$ than that of the WSPG at the Old Field 1 and/or Overgrazing disturbance types (Figure 5). This was most likely because of the creation of nude, un-vegetated patches as a result of abusive over-grazing in those disturbance types. Legume production at these excessively overgrazed locations (e.g. Medicago minima) has been particularly high during wet years in similar arid to semiarid zones (see Fresnillo Fedorenko et al., 1991).

The preferred, late-seral $N$. clarazii and $P$. ligularis showed a greater $(\mathrm{P}<0.05)$ ANPP than the earlier-seral, intermediate $P$. speciosa and the non-preferred $A$. ambigua and $N$. trichotoma in 23 out of 27 comparisons among these species in the Control, Burning and Shrub Control disturbance types. In the Old Field 1, Old Field 2 and Overgrazing disturbance types, however, $N$. clarazii, $P$. ligularis, $P$. speciosa, A. ambigua and $N$. trichotoma showed a similar ( $>>0.05)$ ANPP during 1984-1992 with only a few exceptions [i.e., (1) A. ambigua, Old Field 1, 1984, and (2) N. clarazii, Old Field 2 in 1991, and Overgrazing in 1984]. These results indicate that ANPP would be most likely greater in the late-seral, preferred (e.g., N. clarazzii, P. ligularis) than in the earlierseral, non-preferred (e.g., A. ambigua, P. speciosa) perennial grasses under good management conditions.

\section{REFERENCES}

[1] Archer, S., Smeins, F. E. (1991): Ecosystem-level processes. - In: Heitschmidt, R.K., Stuth, J.W. (Eds.) Grazing Management. An ecological perspective, Timber Press, Portland, 109-139. 
[2] Baker, S. L., Powell, J., Morrison, R. D., Strizke, J. F. (1980): Effects of atrazine, 2,4-D and fertilizer on crude protein content of Oklahoma Tall-Grass Prairie. - Journal of Range Management 33: 404-408.

[3] Bartos, D .L., Brown, J. F., Booth, G. D. (1994): Twelve years biomass response in aspen communities following fire. - Journal of Range Management 47: 79-83.

[4] Bedunah, D. J., Sosebee, R. E. (1995): Wildland plants. Physiological Ecology and Developmental morphology, Society for Range Management, Denver, U.S.A.

[5] Bertiller, M. B. (1996): Grazing effects on sustainable semiarid rangelands in Patagonia. The state and dynamics of the soil seed bank. - Environmental Management 20: 123-132.

[6] Bertiller, M. B. (1998): Spatial patterns of the germinable soil seed bank in northern Patagonia. - Seed Science Research 8: 39-45.

[7] Bonan, G. B. (2002): Agroecosystems. - Ecological Climatology: concepts and applications. - Cambridge University Press, Cambridge, U.S.A, 508-521.

[8] Bontti, E. E., Bóo, R. M., Lindstrom, L. I., Elía, O. R. (1999): Botanical composition of cattle and vizcacha diets in central Argentina. - Journal of Range Management 52: 370377.

[9] Bóo, R. M. (1990): Algunos aspectos a considerer en el empleo del fuego. - Revista de la Facultad de Agrononía de la UNLPampa 5: 63-80.

[10] Bóo, R. M., Lindstrom, L. I., Elia, O. R., Mayor, M. D. (1993): Botanical composition and seasonal trend of cattle diets in central Argentina. - Journal of Range Management 46: 479-482.

[11] Bóo, R. M., Pelaez, D. V., Bunting, S. C., Elia, O. R., Mayor, M. D. (1996): Effect of fire on grasses in central semi-arid Argentina. - Journal of Arid Environments 32: 259-269.

[12] Busso, C. A. (1997): Towards an increased and sustainable production in semiarid rangelands of Central Argentina: Two decades of research. - Journal of Arid Environments 36: 197-210.

[13] Busso, C. A., Giorgetti, H. D., Montenegro O. A., Rodríguez G. D. (2004): Perennial grass species richness and diversity on Argentine rangelands recovering from disturbance. - ФYTON, International Journal of Experimental Botany 73: 9-27.

[14] Busso, C .A., Bolletta, A. I., Flemmer, A. C., Montani, T. (2008): Influence of field soil water status on arbuscular mycorrhiza in three semi-arid perennial grasses of different successional stages in rangelands of central Argentina. - Annales Botanici Fennici 45: 435-447.

[15] Busso, C .A., Bóo, R. M., Peláez, D.V. (1993): Fire effects on bud viability and growth of Stipa tenuis in semiarid Argentina. - Annals of Botany 71: 377-381.

[16] Busso, C. A., Richards, J. H. (1995): Drougth and clipping effect on tiller demography and growth of two tussock grasses in Utah. - Journal of Arid Environments 29: 239-251.

[17] Cabrera, A. L. (1976): Regiones fitogeográficas Argentinas. Enciclopedia Argentina de Agricultura y Jardinería, Tomo II, Editorial ACME, S.A.C.I Buenos Aires, Argentina.

[18] Cano, E. (1988): Pastizales naturales de La Pampa. Descripción de las especies más importantes, Convenio AACREA-Provincia de La Pampa, La Pampa, Argentina.

[19] Cenzano, A. M., Varela, M. C., Bertiller, M. B., Luna, M. V. (2013): Effect of drought on morphological and functional traits of Poa ligularis and Pappostipa speciosa, native perennial grasses with wide distribution in Patagonian rangelands, Argentina. Australian Journal of Botany 61: 383-393.

[20] Cook, J. G., Hershey, T. J, Irwin, L. L. (1994): Vegetative response to burning on Wyoming mountain-shrub big game ranges. - Journal of Range Management 47: 296302.

[21] Cramer, V. A., Hobbs, R. J., Standish, R.J. (2008): What's new about old fields?. Land abandonment and ecosystem assembly. - Trends in Ecology and Evolution 23: 104-112.

[22] Daubenmire, R. (1959): A canopy-coverage method for vegetation analysis. Northwestern Scientist 33: 43-64. 
[23] Digiuni, D. (1983): Métodos de desmonte y su impacto sobre el pastizal natural en el noroeste de Río Negro. - Estación Experimental IDEVI, Serie Técnica 11: 1-73.

[24] Di Rienzo, J. A, Casanoves, F., Balzarini, M. G, Gonzalez, L., Tablada, M., Robledo, C. W. (2013): InfoStat versión 2013. Grupo InfoStat, FCA, Universidad Nacional de Córdoba, Argentina

[25] Distel, R. A., Bóo R. M. (1996): Vegetation states and transitions in temperate semi-arid rangeland of Argentina. - In: West, N (Ed.) Proceedings of the Fifth International Rangeland Congress, Society for Range Management, Denver, U.S.A., 117-118.

[26] Distel, R. A., Peláez, D. V., Fernández, O. A. (1992): Germination of Piptochaetium napostaense (Speg.) Hackel and Stipa tenuis Phil. and seedling survival under field conditions. - Rangeland Journal 14: 49-55.

[27] Du, F., Liang, Z., Xu, X., Shan, L., Zhang, X. (2007): Community biomass of abandoned farmland and its effects on soil nutrition in the Loess hilly region of Northern Shaanxi, China. - Acta Ecologica Sinica 27: 1673-1683.

[28] Fernández, O. A., Busso, C. A. (1999): Arid and semi-arid rangelands: two thirds of Argentina. - In: Arnalds, O., Archer, S. (Eds.) Case Studies of Rangeland Desertification, Agricultural Research Institute, Reykjavik, Iceland, 41-60.

[29] Fernández, R .J., Paruelo, J. M. (1993): Estepas arbustivo-graminosas de Stipa spp. del centro-oeste del Chubut. - In: Paruelo, . M.., Bertiller, M. B., Schlichter, T., Coronato F. (Eds.) Secuencias de deterioro en distintos ambientes patagónicos. Su Caracterización mediante el modelo de estados y transiciones, Convenio Argentino-Alemán de Cooperación Técnica INTA-GTZ. Proyecto LUDEPA-SME. San Carlos de Bariloche, Argentina, 40-46.

[30] Flemmer, A. C., Busso, C. A., Fernández, O. A., Montani, T. (2003): Effects of defoliation under varying soil water regimes on aboveground biomass of perennial grasses. - Arid Soil Research and Management 17: 139-152.

[31] Fresnillo Fedorenko, D. E., Fernández, O. A., Busso, C. A. (1991): Forage production of the annual legume Medicago minima in semiarid rangelads of central Argentina. - In: International Rangeland Congress. Montpellier, France, 372-374.

[32] Gartner, F. R. (1988): Improvements practices that increase range efficiency. - In: White, R.S., Short, R.E. (Eds.) Achieving Efficient use of Rangeland Resources, Montana Agriculture Experiment Station, Montana, U.S.A., 86-91.

[33] Gartner, F. R., White, E. M. and Butterfield, R. I. (1986): Mechanical treatment and burning for high quality range forage. - In: Agriculture Experiment Station and Coop Extension Service, Brookings, 135-140.

[34] Giorgetti, H. D., Manuel, Z., Montenegro, O. A., Rodríguez, G. D., Busso, C. A. (2000): Phenology of some herbaceous and woody species in central, semiarid Argentina. ФYTON, International Journal of Experimental Botany 69: 91-108.

[35] Giorgetti, H. D., Montenegro, O. A., Rodríguez, G. D., Busso, C. A. (1999): Influencia de manejos previos en la Provincia Fitogeográfica del Monte: Porcentaje de cobertura. XIX Reunión de la Asociación Argentina de Ecología, Tucumán, 100.

[36] Gittins Lopez, C. G. (2011): Mecanismos de persistencia de Poa ligularis expuesta a varias frecuencias de defoliación en el noroeste de la Patagonia. PhD Dissertation, Universidad Nacional del Comahue, Bariloche, Río Negro, Argentina. 370 p.

[37] Griffith, L. W., Schuman, G. E., Rauzi, F., Baumgartner, R. E. (1985): Mechanical renovation of shortgrass prairie for increased herbage production. - Journal of Range Management 38: 7-10.

[38] Haferkamp, M. R., Volesky, J. D., Borman, M. M., Heithschmidt, R. K., Currie, P. O. (1993): Effects of mechanical treatments and climatic factors on the productivity of Northern Great Plains rangelands. - Journal of Range Management 46: 346-350.

[39] Holechek, J.L. (1981): Livestock Grazing Impacts on Public Lands: A Viewpoint. Journal of Range Management 34: 251-254. 
[40] Instituto de Botánica Darwinion, http://www2.darwin.edu.ar/Proyectos/ FloraArgentina/BuscarEspecies.asp, Access date: 26 February 2016.

[41] Huang, Y., Street-Perrott, F. A, Metcalfe, S. E., Brenner, M., Moreland, M., Freeman, K. H. (2001): Climate change as the dominant control on glacial-interglacial variations in $\mathrm{C}_{3}$ and $\mathrm{C}_{4}$ plant abundance. - Science 293: 1647-1651.

[42] Huxman, T. E., Smith, M. D., Fay, P. A., Knapp, A. K., Shaw, M. R., Lolk, M. E., Smith, S. D., Tissue, D. T., Zak, J. C., Weltzin, J. F., Pockman, W. T., Sala, O. E., Haddad, B. M., Harte, J., Koch, G. W., Schwinning, S., Small, E. E., Williams, D. G. (2004): Convergence across biomes to a common rain-use efficiency. - Nature 429: 651-654.

[43] Ithurrart, L. S. (2014): Efectos de la defoliación luego de la quema de gramíneas perennes nativas, palatables y no palatables, en el sudoeste Bonaerense. PhD Dissertation, Departamento de Agronomía, Universidad Nacional del Sur, Bahía Blanca, Argentina. $203 \mathrm{pp}$.

[44] Jacoby, P. W., Meadors, C. H. (1982): Control of sand shinnery oak (Quercus havardii) with pelleted picloram and tebuthiuron. - Weed Science 30: 594-597.

[45] Klemmedson, J. O., Smith, J. G. (1964): Cheatgrass (Bromus tectorum L.). - The Botanical Review 30: 226-262.

[46] Köhl, L., Oehl, F., van der Heijden, M. G. A. (2014): Agricultural practices indirectly influence plant productivity and ecosystem services through effects on soil biota. Ecological Applications 24: 1842-1853.

[47] Le Houérou, H. N., Bingham, R. L., Skerbek, W. (1988): Relationship between the variability of primary production and the variability of annual precipitation in world arid lands. - Journal of Arid Enrivonments 15: 1-18.

[48] Liu, W., Huang, Y., An, Z., Clemens, S. C., Li, L., Prell, W. L., Ning, Y. (2005): Summer monsoon intensity controls $\mathrm{C}_{4} / \mathrm{C}_{3}$ plant abundance during the last $35 \mathrm{ka}$ in the Chinese Loess Plateau: Carbon isotope evidence from bulk organic matter and individual leaf waxes. - Palaeogeography, Palaeoclimatology, Palaeoecology 220: 243-254.

[49] Llorens, E.M. (1995): Viewpoint: the state and transition model applied to the herbaceous layer of Argentina's calden forest. - Journal of Range Management 48: 442-447.

[50] Martin, S. C., Morton, H. L. (1980): Response of falsemesquite, native grass and forbs, and lovegrass after spraying with picloram. - Journal of Range Management 35: 219-222.

[51] Mazzarino, M. J., Bertiller, M. B., Sain, C. L., Satti, P., Coronato, F .R. (1998): Soil nitrogen dynamics in northern Patagonia steppe under different precipitation regimes. Plant and Soil 202: 125-131.

[52] Meyer, R. E., Bovey, R. W. (1985): Response of herbaceous vegetation in East-Central Texas to herbicides. - Weed Science 33: 81-90.

[53] Moreira, F., Arianoutsou, M., Corona, P., De las Heras, J. (2012): Post-Fire management and restoration of southern european forests. - Springer, Dordrecht, The Netherlands.

[54] Moretto, A. S., Distel, R. A. (1997): Competitive interactions between palatable and unpalatable grasses native to a temperate semi-arid grassland of Argentina. - Plant Ecology 130: 155-161.

[55] Moretto, A.S., Distel, R.A. (1999): Effects of selective defoliation on the competitive interaction between palatable and unpalatable grasses native to a temperate semi-arid grassland of Argentina. - Journal of Arid Environments 42: 167-175.

[56] Moretto, A. S., Distel, R. A., Didoné, N .G. (2001): Decomposition and nutrient dynamics of leaf litter and roots from palatable and unpalatable grasses in a semi-arid grassland. - Applied Soil Ecology 18: 31-37.

[57] Moretto, A. S., Didoné, N. G., Distel, R. A. (2013): Reabsorción de nitrógeno en gramíneas perennes de diferente palatabilidad, nativas del Caldenal. - Ecologia Austral 23: $1-7$

[58] Mueller-Dombois, D., Ellenberg, H. (1974): Aims and Methods of Vegetation Ecology. - John Wiley \& Sons, New York, U.S.A.

[59] Paez, A., Busso, C. A., Montenegro, O. A., Rodríguez, G. D., Giorgetti, H. D. (2005): 
Seed weight variation and its effects on germination in Stipa species. - ФYTON, International Journal of Experimental Botany 74: 1-14.

[60] Pearcy, R. W., Ehleringer, J. (1984): Comparative ecophysiology of $\mathrm{C}_{3}$ and $\mathrm{C}_{4}$ plants. Plant Cell and Environment 7: 1-13.

[61] Peláez, D. V, Bóo, R. M., Mayor, M. D. (2003): El Fuego y la Vegetación del Sur del Caldenal. - In: Kunst, C.R., Bravo, S., Panigatti, J.L. (Eds.) Fuego en los Ecosistemas Argentinos. Ediciones INTA, Buenos Aires, Argentina, 71-78.

[62] Peláez, D. V., Giorgetti, H. D., Montenegro, O. A., Elía, O. R., Rodríguez, G. R., Bóo, R. M., Mayor, M. D., Busso, C. A. (2010): Vegetation response to a controlled fire in the Phytogeographical Province of the Monte, Argentina. - ФYTON, International Journal of Experimental Botany 79: 169-176.

[63] Perelman, S. B., León, R. J. C., Bussacca, J. P. (1997): Floristic changes related to grazing intensity in a Patagonian shrub steepe. - Ecography 20: 400-406.

[64] Rúgolo de Agrasar, Z. E., Steibel, P. E. and Troiani, H. O . (2005): Manual ilustrado de las gramíneas de la Provincia de La Pampa. Universidad Nacional de La Pampa, Santa Rosa, Universidad Nacional de Rio Cuarto, Córdoba, Argentina.

[65] Saint Pierre, C., Busso, C. A., Montenegro, O. A., Rodríguez, G. D., Giorgetti, H. D., Montani, T., Bravo, O. A. (2002): Root proliferation in perennial grasses of low and high palatability. - Plant Ecology 165: 161-169.

[66] Saint Pierre, C., Busso, C. A., Montenegro, O. A,, Rodríguez, G. D., Giorgetti, H. D., Montani, T., Bravo, O. A. (2004a): Defoliation tolerance and ammonium uptake rate in perennial tussock grasses. - Journal of Range Management 57: 82-88.

[67] Saint Pierre, C., Busso, C. A., Montenegro, O. A., Rodríguez, G. D., Giorgetti, H. D., Montani, T., Bravo, O. (2004b): Direct assessment of competitive ability and defoliation tolerance in perennial grasses. - Canadian Journal of Plant Science 84: 195-204.

[68] Saint Pierre, C., Busso, C. A., Montenegro, O. A., Rodríguez, G. D., Giorgetti, H. D., Montani, T., Bravo, O. A. (2004c): Soil resource acquisition mechanisms, nutrient concentrations and growth in perennial grasses. - Interciencia 29: 303-311.

[69] Sala, O. E. (1988): The effect of herbivory on vegetation structure. - In: Werger, M. J. A., van der Aart, P. J. M., During, H. J, Verhoeven, J. T. A. (Eds.) Plant form and vegetation structure. - Academic Publishing, Verboeven, 317-330.

[70] Sala, O. E., Lauenroth, W.K. (1982): Small rainfall events: an ecological role in semiarid regions. - Oecologia 53: 301-304.

[71] Schlesinger, W. H., Reynolds, J. F., Cunningham, G. L., Huenneke, L. F., Jarrell, W. M., Virginia, R. A., Whitford, W. G. (1990): Biological feedbacks in global desertification. Science 247: 1043-1048.

[72] Singh, J. S, Lauenroth, W. K., Steinhorst, R. K. (1975): Review and assessment of various techniques for estimating net aerial primary production in grasslands from harvest data. - Botanical Review 41: 181-232.

[73] Sturges, D. L. (1993): Soil-water and vegetation dynamics through 20 years after big sagebrush control. - Journal of Range Management 46: 161-169.

[74] Tizón, F. R., Peláez, D. V., Elía, O. R. (2010): The Influence of controlled fires on a plant community in the South of the Caldenal, and its relationship with a regional state and transition model. - Phyton, International Journal of Experimental Botany 79: 141-146.

[75] Torres, Y. A., Busso, C. A., Montenegro, O. A., Ithurrart, L., Giorgetti, H., Rodríguez, G., Bentivegna, D., Brevedan, R., Fernández, O., Mujica, M. M., Baioni, S., Entío, J., Fioretti, M., Tucat, G. (2013): Plant growth and survival of five perennial grass genotypes exposed to various defoliation managements in arid Argentina. - Grass and Forage Science 69: 580-595.

[76] Torres, Y. A., Busso, C. A., Montenegro, O. A., Ithurrart, L., Giorgetti, H., Rodríguez, G., Bentivegna, D., Brevedan, R., Fernández, O., Mujica, M. M., Baioni, S., Entío, J., Fioretti, M., Tucat, G. (2014): Root proliferation in perennial grasses in arid Patagonia, Argentina. - Journal of Arid Land 6: 195-204. 
[77] Vallentine, J. F. (1990): Grazing management. - Academic Press, San Diego, U.S.A.

[78] Volesky, J. D., Anderson, B. E., Nichols, J. T. (2010): Perennial Forages for Irrigated Pasture. http://www.ianrpubs.unl.edu/epublic/live/g1502/build/. Access date: $11 \mathrm{Feb}$ 2015.

[79] Walker, L. R. (1999): Ecosystems of disturbed grounds. - Elsevier Science, Amsterdam, The Netherlands.

[80] Webb, W. L., Lauenroth, W. K., Szarek, S. R., Kinerson, R. S. (1983): Primary production and abiotic controls in forests, grasslands, and desert ecosystems in the United States. - Ecology 64: 134-151.

[81] White, L. M. (1985): Stand age, precipitation, and temperature effects on forage yield. Journal of Range Management 38: 39-43.

[82] Wilks, S. S. (1932): Certain generalizations in the analysis of variance. - Biometrika 24: 471-494.

[83] Wright, H. A., Bailey, A. W. (1982): Fire Ecology. - John Wiley and Sons, New York, U.S.A.

[84] Zar, J.H. (1996): Biostatistical analysis $3^{\text {rd }}$ ed. - Prentice Hall, New Jersey, U.S.A. 